\title{
Technology Assessment of
} Solar Energy Systems:

Availability and Impacts of Woody Biomass Utilization in the Pacific Northwest

W. J. Hopp

A. D. Chockie

K. J. Allwine

September 1981

Prepared for the U.S. Department of Energy under Contract DE-AC06-76RLO 1830

Pacific Northwest Laboratory Operated for the U.S. Department of Energy by Battelle Memorial Institute 


\title{
NOTICE
}

This report was prepared as an account of work sponsored by the United States Government. Neither the United States nor the Department of Energy, nor any of their employees, nor any of their contractors, subcontractors, or their employees, makes any warranty, express or implied, or assumes any legal liability or responsibility for the accuracy, completeness or usefulness of any information, apparatus, product or process disclosed, or represents that its use would not infringe privately owned rights.

The views, opinions and conclusions contained in this report are those of the contractor and do not necessarily represent those of the United States Government or the United States Department of Energy.

\author{
PACIFIC NORTHWEST LABORATORY \\ operated by \\ BATTELLE \\ for the \\ UNITED STATES DEPARTMENT OF ENERGY \\ Under Contract DE-AC06-76RLO 1830
}

\author{
Printed in the United States of America \\ Available from \\ National Technical Information Service \\ United States Department of Commerce \\ 5285 Port Royal Road \\ Springfield. Virginia 22151
}

Price: Printed Copy $\$$. $\therefore$ Microfiche $\$ 3.00$

$\begin{array}{cc}\text { •Pages } & \begin{array}{c}\text { NTIS } \\ \text { Selling Price }\end{array} \\ 001-025 & \$ 4.00 \\ 026-050 & \$ 4.50 \\ 051-075 & \$ 5.25 \\ 076-100 & \$ 6.00 \\ 101-125 & \$ 6.50 \\ 126-150 & \$ 7.25 \\ 151-175 & \$ 8.00 \\ 176-200 & \$ 9.00 \\ 201-225 & \$ 9.25 \\ 226-250 & \$ 9.50 \\ 251-275 & \$ 10.75 \\ 276-300 & \$ 11.00\end{array}$


PNL -3933

UC -61

TECHNOLOGY ASSESSMENT OF SOLAR ENERGY SYSTEMS:

AVAILABILITY AND IMPACTS OF WOODY BIOMASS

UTILIZATION IN THE PACIFIC NORTHWEST
W. J. Hopp
A. D. Chockie
K. J. Allwine

September 1981

Prepared for

the U.S. Department of Energy

under Contract DE-ACO6-76RLO 1830

Pacific Northwest Laboratory

Richland, Washington 99352 


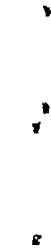


CONTENTS

FOREWORD •

EXECUTIVE SUMMARY $• . \quad$ •

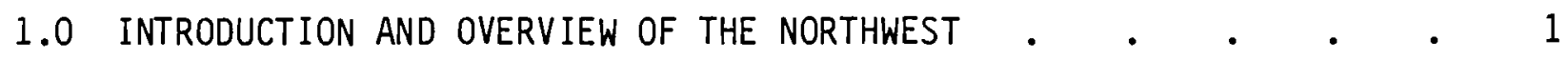

2.0 BIOMASS IN THE NORTHWEST: AVAILABLE INVENTORY • • • • 5

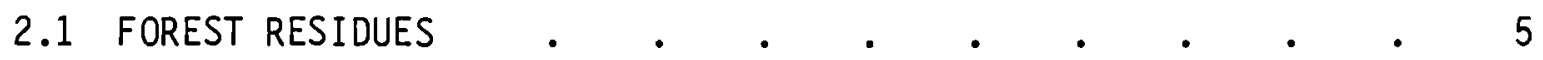

2.2 WOOD MILL WASTES $. \quad . \quad . \quad . \quad . \quad . \quad . \quad . \quad 7$

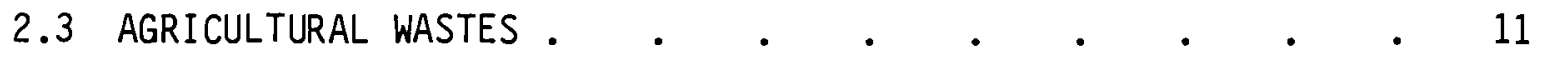

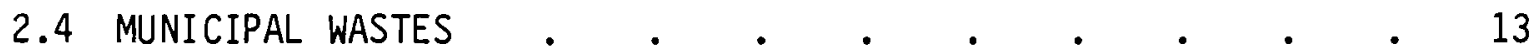

2.5 CAVEATS . . . . . . . . . . . . . . . . 15

3.0 IMPACTS OF FOREST RESIDUE UTILIZATION IN THE NORTHWEST • $~ • \quad$. 17

3.1 COMPETING END USES $•$ •

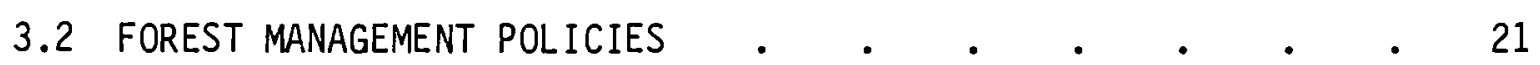

3.3 INJURIES AND DEATHS FROM RESIDUE COLLECTION • • • • • 23

3.4 BIOMASS/CONVENTIONAL FUELS AIR EMISSIONS

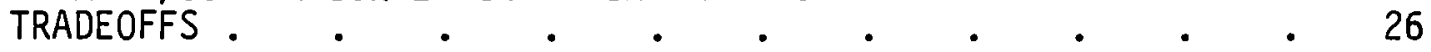

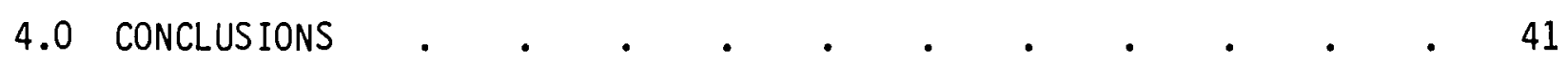

5.0 REFERENCES $. \quad . \quad . \quad . \quad . \quad . \quad . \quad . \quad . \quad . \quad . \quad . \quad 45$

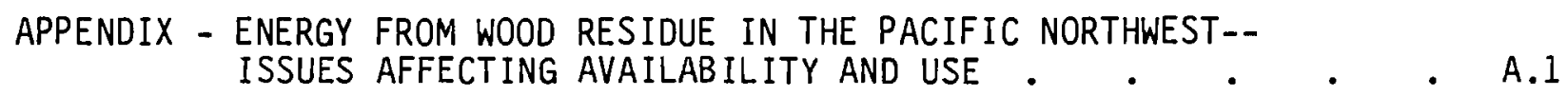




\section{TABLES}

1 Pacific Northwest Commercial Timberland . . . . . . 3

2 Estimated Energy. From Four Sources of Biomass

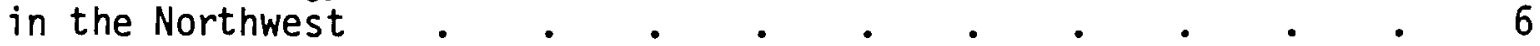

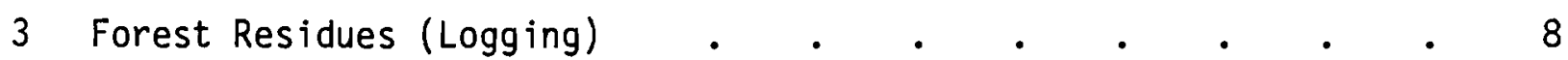

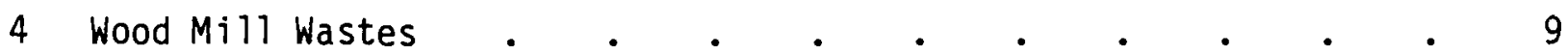

5 Use of Wood Mill Residues in the Northwest (Percent) . . . 10

6 Agricultural Wastes (Crop and Animal) . . . . . . . 12

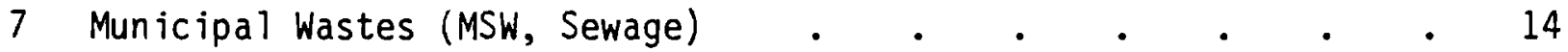

8 Conversion Factors and Heat Values . . . . . . . . . 16

9 Volume and Value of Pulp Material, Export Chips, and Hogged Fuel for Oregon - 1978 .

10 Injuries, Deaths, and Lost Workdays From Commercial

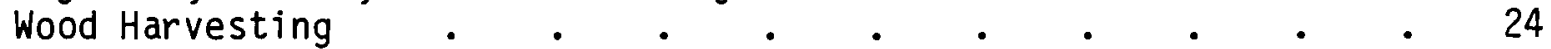

11 Injuries, Deaths, and Lost Workdays From Coal Mining

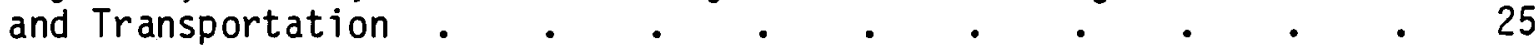

12 Maximum Potential Quantities of Northwest Biomass Annually Available as Fuel - Yr. 2000 . . . . . . . 30

13 Biomass Input Energy and Conventional Energy Displaced by Biomass - Yr. 2000 . . . . . .

14 Direct Combustion Processes - Particulate Emission Factors and Conversion Efficiencies . . . . .

15 Biomass End-Use Energy and Conventional Energy Displaced by Biomass - Yr. 2000 . $. \quad . \quad . \quad . \quad . \quad . \quad . \quad . \quad 36$

16 Biomass Particulate Emissions and Conventional Fuel Emissions Displaced by Biomass - Yr. 2000 . $. \quad . \quad$. $\quad$. 37 


\section{FOREWORD}

This study of biomass in the Pacific Northwest has been performed in support of the Technology Assessment of Solar Energy (TASE) Project. Early TASE analyses indicated that biomass technologies produce more significant impacts than other solar technologies, particularly in the area of air quality. This study supports the initial TASE analyses by providing an examination of the impacts that could result from biomass utilization in the Pacific Northwest.

We would like to thank Dr. John Bergva11, Richard Schaefer, and the many other professionals in the region for their assistance and advice in our efforts. However, the opinions and conclusions expressed in this study are purely the responsibility of the authors. We also extend our thanks to Dr. Greg D'Alessio for this continued support of our work in this area. 


\section{EXECUTIVE SUMMARY}

Energy from biomass sources makes up a large fraction of the solar energy projected in many energy scenarios, including the scenarios used in the Technology Assessment of Solar Energy (TASE) Study. This report reviews the estimates that have been made of the biomass resource base in the Northwest for comparison with the TASE scenarios and presents a preliminary analys is of the issues involved in the collection and use of forest residues as an energy resource.

A literature review shows that the estimated current biomass resource, consisting of forest residues, wood mill wastes, agricultural wastes and municipal wastes, is equivalent to one-quarter to one-third of the total energy consumption in the Northwest. The "Base Case" TASE scenario calls for only 13 percent of current energy in the Northwest to be displaced by biomass sources in the year 2000. However, large discrepancies exist between the estimates of available biomass reported in different sources. These discrepancies are partly due to disagreements over technical issues such as the heat content of various biomass residues, the amount of crop or forest residues that can be safely removed from the land without depleting the nutrient content of the soil or causing an erosion problem, the size of residues that can be economically collected, and the amount of forestland that is too rugged to allow collection of residues. These issues require resolution to refine the estimates of biomass availability in the Northwest.

In addition to examining the technical difficulties in the estimates of the biomass resource base, this report reviews four issues that may serve to constrain the total amount of wood residues available for use as fuel. First, it was found that most currently collected wood residues have a higher value as wood product material than as an energy source. Given rising wood products prices, this factor may severely limit the amount of residues available for energy. Second, the Forest Service policies, particularly the requirement that loggers collect residues for fire prevention purposes, can impact the economics of forest residue collection. Third, an estimate of the injuries and deaths from forest residue collection was made. This estimate showed wood residues to be a more hazardous source of energy than coal. And fourth, an assessment of 
the impacts from the displacement of conventional fuels with biomass was performed. The results indicated that, with the maximum utilization of biomass, the primary impact would be a degradation of the region's air quality due mainly to residential wood burning. These issues pose important barriers to development of biomass energy as well as significant public policy concerns. Further study of these and other issues is necessary to achieve the maximum practical energy from biomass in the Northwest without causing adverse social, environmental and economic impacts. 


\subsection{INTRODUCTION AND OVERVIEW OF THE NORTHWEST}

The Technology Assessment of Solar Energy (TASE) Project, by the Office of Environmental Assessments in DOE, projects 6.0 quads of solar energy in the U.S. under the Base Case Scenario. Of this total, 3.1 quads, or $52 \%$, are from biomass sources. The same scenario forecasts 0.452 quads of solar energy for the Northwest Region (Region X), 0.217 quads (48\%) of which is biomass. Clearly, biomass, which includes forest residues, wood mill wastes, agricultural residues, and municipal waste, represents a potentially significant energy source, in the Northwest and nationally. However, estimating the actual quantities of biomass available for use as fuel is not a straightforward task. Different authors base their estimates on different assumptions concerning the biomass resource base itself, as well as the practical problems involved in using it as an energy source. The purpose of this paper is to summarize the estimates of the available biomass inventory in the Northwest, discuss the difficulties in interpreting these estimates, and identify the impacts associated with using biomass as an energy resource.

The Northwest Region, which consists of Alaska, Idaho, Oregon, and Washington, has many attributes that give it a specific character of its own with respect to biomass energy. The western portions of Washington and Oregon are densely forested, predominantly with Pacific Douglas Fir, over a rugged landscape. The terrain and species of trees make the logging operations and biomass potential markedly different in the Northwest than in the flatter Southeast portions of the United States. The eastern sections of Washington and Oregon are very arid and contain much irrigated agriculture. The dryness of the land makes wind erosion a problem that must be faced if agricultural residues are removed from the field for use as fuel. The far eastern edges of Washington and Oregon and Idaho have rugged terrain and are forested with a mix of Juniper, Ponderosa Pine, Western Larch, Cedar, White Pine, and Douglas Fir. In relation to its population Alaska has considerable forest resources that could provide sources of biomass energy. Overall, the Northwest Region does not have many centers of dense population. This may limit the number of practical applications for municipal waste as an energy source. However, the population in the Northwest is steadily growing and this situation may change in the future. 
Because of the large amount of logging that takes place in the Pacific Northwest, forest residues and wood mill wastes are particularly important potential sources of energy in this region. This makes the issue of commercial timberland ownership an important factor affecting the institutional problems facing biomass use in the Northwest. Table 1 shows a breakdown of the commercial timberland in the Northwest by owner. As this table shows, the majority of commercial timberland in the Northwest is publicly-owned. Of the public timberland, most is administered by the U.S.D.A. Forest Service. Smaller amounts of public timberland are administered by the Bureau of Land Management, Indians, State and County agencies and miscellaneous federal agencies. About one-third of the commercial timberland is privately-owned. Of the private timberland, about half is owned by the forest products industry. Overall, the large fraction of timberland that is publicly administered in the Northwest means that the policies of the involved public agencies, particularly the Forest Service, will have a substantial impact on the development of forest residues as an energy resource in this region. 
TABLE 1. Pacific Northwest Commercial Timberland (thous ands of acres)

\begin{tabular}{|c|c|c|c|c|c|c|c|c|c|c|c|c|c|}
\hline & \multirow[b]{2}{*}{$\begin{array}{l}\text { All } \\
\text { Owner- } \\
\text { Ship }\end{array}$} & \multicolumn{6}{|c|}{ PUBLIC } & & & \multicolumn{4}{|c|}{ PRIVATE } \\
\hline & & $\begin{array}{l}\text { Total } \\
\text { Public }\end{array}$ & $\begin{array}{l}\text { EDERAL } \\
\text { Total } \\
\text { Fed. }\end{array}$ & $\begin{array}{l}\text { National } \\
\text { Forest }\end{array}$ & B.L.M. & Indian & $\begin{array}{l}\text { Misc. } \\
\text { Fed. }\end{array}$ & State & $\begin{array}{l}\text { County } \\
\text { Munt. }\end{array}$ & $\begin{array}{l}\text { Total } \\
\text { Private }\end{array}$ & $\begin{array}{l}\text { Forest } \\
\text { Industry }\end{array}$ & Farms & $\begin{array}{l}\text { Misc. } \\
\text { Private }\end{array}$ \\
\hline $\begin{array}{l}\text { Alaska } \\
\text { Cuastal }\end{array}$ & 5,639 & 5,609 & 5,256 & 5,144 & 83 & 25 & 4 & 353 & 0 & 30 & 0 & 0 & 30 \\
\hline Idaho & 15,192 & 12,171 & 11,291 & 10,731 & 501 & 51 & 7 & 861 & 18 & 3,020 & 946 & 777 & 1,297 \\
\hline $\begin{array}{l}\text { Oregon } \\
\text { Eastern } \\
\text { Western } \\
\text { Total }\end{array}$ & $\begin{array}{l}11,038 \\
14,635 \\
25,673\end{array}$ & $\begin{array}{r}7,767 \\
7,752 \\
15,519\end{array}$ & $\begin{array}{r}7,697 \\
6,884 \\
14,581\end{array}$ & $\begin{array}{r}7,173 \\
4,830 \\
12,003\end{array}$ & $\begin{array}{r}200 \\
2,046 \\
2,246\end{array}$ & $\begin{array}{r}316 \\
8 \\
324\end{array}$ & $\begin{array}{l}8 \\
0 \\
8\end{array}$ & $\begin{array}{r}65 \\
735 \\
800\end{array}$ & $\begin{array}{r}5 \\
133 \\
138\end{array}$ & $\begin{array}{r}3,271 \\
6,883 \\
10,154\end{array}$ & $\begin{array}{l}1,582 \\
3,624 \\
5,206\end{array}$ & $\begin{array}{l}1,230 \\
1,620 \\
2,850\end{array}$ & $\begin{array}{r}459 \\
1,639 \\
2,098\end{array}$ \\
\hline $\begin{array}{c}\text { Washington } \\
\text { Eastern } \\
\text { Western } \\
\text { Total }\end{array}$ & $\begin{array}{r}8,410 \\
9,991 \\
18,401\end{array}$ & $\begin{array}{l}5,395 \\
4,123 \\
9,518\end{array}$ & $\begin{array}{l}4,652 \\
2,581 \\
7,233\end{array}$ & $\begin{array}{l}3,103 \\
2,321 \\
5,424\end{array}$ & $\begin{array}{r}46 \\
2 \\
48\end{array}$ & $\begin{array}{r}1,403 \\
190 \\
1,593\end{array}$ & $\begin{array}{r}100 \\
68 \\
168\end{array}$ & $\begin{array}{r}737 \\
1,379 \\
2,116\end{array}$ & $\begin{array}{r}6 \\
163 \\
169\end{array}$ & $\begin{array}{l}3,015 \\
5,868 \\
8,883\end{array}$ & $\begin{array}{r}750 \\
3,598 \\
4,348\end{array}$ & $\begin{array}{r}1,429 \\
437 \\
1,866\end{array}$ & $\begin{array}{r}836 \\
1,833 \\
2,669\end{array}$ \\
\hline Northwest Region & $\begin{array}{l}64,905 \\
(100 \%)\end{array}$ & $\begin{array}{r}42,817 \\
(66 \%)\end{array}$ & $\begin{array}{r}38,361 \\
(59 \%)\end{array}$ & $\begin{array}{r}33,302 \\
(51 \%)\end{array}$ & $\begin{array}{r}2,878 \\
(4 \%)\end{array}$ & $\begin{array}{r}1,993 \\
(3 \%)\end{array}$ & $\begin{array}{c}187 \\
(0.3 \%)\end{array}$ & $\begin{array}{r}4,130 \\
(6 \%)\end{array}$ & $\begin{array}{c}325 \\
(0.5 \%)\end{array}$ & $\begin{array}{r}22,087 \\
(34 \%)\end{array}$ & $\begin{array}{r}10,500 \\
(16 \%)\end{array}$ & $\begin{array}{r}5,493 \\
(8 \%)\end{array}$ & $\begin{array}{r}6,094 \\
(9 \%)\end{array}$ \\
\hline
\end{tabular}




\subsection{BIOMASS IN THE NORTHWEST: AVAILABLE INVENTORY}

A compilation of various estimates of the amount of biomass presently available for use as fuel in the Northwest was produced based on four Northwest resource studies (References $2,3,4,5$ ). (a) These estimates, shown in Table 2, are listed in four categories: agricultural wastes, forest residues, wood mill wastes, and municipal wastes. Other sources of biomass, such as silvicultural farms and kelp are generally considered to offer less potential than those listed in Table 2, and are therefore not considered in this study. $(3,5)$

As a total energy resource, Table 2 shows biomass inventories to amount to between 379.6 and $552.8 \mathrm{TBtu}\left(10^{12} \mathrm{Btu}\right)$. Since energy consumption in the Northwest in 1975 was approximately 1.68 quads, ${ }^{(3)}$ this estimate of biomass inventories represents 22.6 to $32.9 \%$ of the total energy demand in the Northwest. As of the mid-1970s it is estimated that biomass, mainly in the form of wood-burning, supplies $84 \mathrm{Btu}$, or $5 \%$ of the total energy demand in this region. (3) However, as shown by the range of estimates in Table 2, some disagreement exists over the amount of biomass available as fuel. To examine more closely the individual estimates of biomass availability and some of the difficulties in interpreting these estimates, a brief discussion of each type of biomass is presented below.

\subsection{FOREST RESIDUES}

Forest residues are those parts of the tree that are currently allowed to remain in the woods after removing merchantable lumber. These parts include tops, branches, needles and leaves, stumps, and roots. However, not all of the forest residues are generally considered available. Most often, leaves, needles, roots, and stumps are excluded because of the difficulties involved in collection. Small branches (less than 3 to 4 inches in diameter) are also often considered impractical to collect. The terrain also plays a role in the amount of residue available. The Department of Natural Resources (DNR) ${ }^{(5)}$

(a) It should be noted that while Region $X$ includes Alaska, because of the unavailability of data, Alaska is not included in this survey. Thus, the Northwest Region here refers to Idaho, Oregon and Washington. 
TABLE 2. Estimated Energy from Four Sources of Biomass in the Northwest

\begin{tabular}{l|c|c|c} 
Type of Residue & $\begin{array}{c}\text { Available } \\
\text { Heat } \\
\text { Value } \\
\left(10^{\text {Btu }}\right.\end{array}$ & $\begin{array}{c}\text { Percent } \\
\text { of } \\
\text { Total }\end{array}$ & $\begin{array}{c}\text { Range } \\
\text { of } \\
\text { Estimates* } \\
\text { (percent) }\end{array}$ \\
\hline $\begin{array}{l}\text { Agricultural } \\
\text { Wastes }\end{array}$ & $141.0-263.8$ & $37-48$ & 87 \\
Forest Residues & $146.2-196.0$ & $35-39$ & 34 \\
Wood Mill Wastes & $54.7-58.0$ & $10-16$ & 6 \\
Municipal Wastes & 35.0 & $6-9$ & -- \\
\hline \multicolumn{1}{c|}{ TOTAL } & $376.9-552.8$ & 100 & 47
\end{tabular}

* (High Estimate-Low Estimate) $\div$ Low Estimate

Source: References 2, 3, 4 (1976-1977) 
includes a factor of reduction in their total forest residue estimate to account for their assumption that it is not realistic to collect residues on terrain with slopes in excess of 30. A final issue of controversy arises over the amount of forest residue that can be safely removed from the land without violating the principles of good forest management. Some authors argue that the humus, roots and fine residues will be sufficient to maintain soil nutrients and avoid erosion, while removing larger residues for use as fuel will decrease the risk of forest fires and insect-borne disease. (12) However, despite the several points of disagreement listed above, Table 3 shows that there is not a great deal of variation among the estimates of total available forest residues in the Northwest.

\subsection{WOOD MILL WASTES}

Mill wastes are the portions of the harvested wood that are not used by the forest products industry. This includes sawdust, wood chips, bark, slabs, edging, and trim. As shown in Table 4, the total volume of mill residue produced annually in the Northwest is vast, amounting to over 26,000,000 dry tons, or nearly the equivalent of a half quad of energy. (3) However, unlike forest residues, a large portion of mill wastes are already being used. Figure 1 shows that $54 \%$ of mill wastes in Washington are presently used for pulp and board, while another $31 \%$ are used by the wood processing industry as fuel. Only $7 \%$ are currently unused. The numbers in Table 4 for available mill residues represent only these unused mill wastes and do not include wastes already used as fuel. This is only a matter of definition by the referenced sources. Mill wastes used by the wood industry as fuel are certainly a form of biomass energy, and are largely responsible for the 5\% of the total Northwest energy demand that is presently supplied by biomass sources. However, these wastes do not offer additional potential for replacing conventional fuels with biomass because they are already being used; therefore they were left out of Table 4 .

Table 5 affirms the fact that a large percentage of wood mill wastes is currently being used, either as fuel or sold to make pulp and board products. However, Table 5 also shows that the fraction of mill residues that is presently unused, and therefore presumably available for use as fuel, varies among states. Idaho has four times as much unused mill residues as Oregon at the present time. 
TABLE 3. Forest Residues (Logging)

\begin{tabular}{|c|c|c|c|c|c|}
\hline & $\begin{array}{c}\text { Annual } \\
\text { Production } \\
\text { (dry tons) }\end{array}$ & $\begin{array}{l}\text { Annual } \\
\text { Available } \\
\text { Portion } \\
\text { (dry tons) }\end{array}$ & $\begin{array}{l}\text { Total Heat } \\
\text { Value } \\
\left(10^{12} \text { Btu }\right)\end{array}$ & $\begin{array}{c}\text { Available } \\
\text { Heat } \\
\text { Yalue } \\
10 \text { Btu) }\end{array}$ & Source \\
\hline Washington & $\begin{array}{c}6,150,600 \\
3,354,734 \\
-- \\
--\end{array}$ & $\begin{array}{l}4,373,627 \\
3,354,734(6) \\
4,411,765(7) \\
4,388,235(7)\end{array}$ & $\begin{array}{c}102.8 \\
57.03(7) \\
-- \\
--\end{array}$ & $\begin{array}{l}73.1 \\
57.03(7) \\
75.0 \\
74.6\end{array}$ & $\begin{array}{l}\operatorname{DNR}^{(5)} \\
\operatorname{SRI}^{(2)} \\
\text { Miles (4) } \\
\text { NEPP(3) }\end{array}$ \\
\hline Oregon & $\begin{array}{c}4,771,614 \\
-- \\
--\end{array}$ & $\begin{array}{l}4,771,614(5) \\
6,532,941^{(7)} \\
6,532,941(7)\end{array}$ & $\begin{array}{l}81.1^{(7)} \\
-- \\
--\end{array}$ & $\begin{array}{l}81.1^{(7)} \\
108.0 \\
108.0\end{array}$ & $\begin{array}{l}\text { SRI (2) } \\
\text { Miles (4) } \\
\text { NEPP (3) }\end{array}$ \\
\hline Idaho & $\begin{array}{l}474,932 \\
-- \\
--\end{array}$ & $\begin{array}{l}474,932(6) \\
764,706(7) \\
782,353^{(7)}\end{array}$ & $\begin{array}{l}8.1^{(7)} \\
-- \\
--\end{array}$ & $\begin{array}{l}8.1^{(7)} \\
13.0 \\
13.3\end{array}$ & $\begin{array}{l}\text { SRI (2) } \\
\operatorname{Miles}(4) \\
\operatorname{NEPP}(3)\end{array}$ \\
\hline TOTAL & $\begin{array}{c}8,601,380 \\
-- \\
--\end{array}$ & $\begin{array}{l}8,601,289(6) \\
11,529,412^{(7)} \\
11,523,529(7)\end{array}$ & $\begin{array}{c}146.2^{(7)} \\
-- \\
--\end{array}$ & $\begin{array}{l}146.2^{(7)} \\
196.0 \\
195.9\end{array}$ & $\begin{array}{l}\operatorname{SRI}(2) \\
\text { Miles (4) } \\
\operatorname{NEPP}(3)\end{array}$ \\
\hline
\end{tabular}

Note: Numbers without a footnote were obtained directly from the referenced source. 
TABLE 4. Wood Mill Was tes

\begin{tabular}{|c|c|c|c|c|c|}
\hline & $\begin{array}{c}\text { Annual } \\
\text { Production } \\
\text { (dry tons) }\end{array}$ & $\begin{array}{l}\text { Annual } \\
\text { Available } \\
\text { Portion } \\
\text { (dry tons) }\end{array}$ & $\begin{array}{l}\text { Total Heat } \\
\text { Value } \\
\left(10^{12} \text { Btu }\right)\end{array}$ & $\begin{array}{l}\text { Available } \\
\text { Heat } \\
\text { Value } \\
\text { (1012 Btu) }\end{array}$ & Source \\
\hline Washington & $\begin{array}{l}5,925,940 \\
6,523,440 \\
-- \\
--\end{array}$ & $\begin{array}{c}649,287 \\
753,726^{(11)} \\
1,117,647^{(8)} \\
1,117,647^{(8)}\end{array}$ & $\begin{array}{l}105.05 \\
110.89(8) \\
-- \\
--\end{array}$ & $\begin{array}{l}11.51 \\
12.8^{(8)} \\
19.0 \\
19.0\end{array}$ & $\begin{array}{l}\operatorname{DNR}^{(5)} \\
\operatorname{SRI}^{(2)} \\
\text { Miles } \\
\operatorname{NEPP}^{(4)}(3)\end{array}$ \\
\hline Oregon & $\begin{array}{c}17,000,186 \\
-- \\
--\end{array}$ & $\begin{array}{l}1,478,700^{(11)} \\
1,470,588^{(8)} \\
1,464,706^{(8)}\end{array}$ & $\begin{array}{c}289.0^{(8)} \\
-- \\
-\end{array}$ & $\begin{array}{l}25.1^{(8)} \\
25.0 \\
24.9\end{array}$ & $\begin{array}{l}\text { SRI (2) } \\
\text { Miles (4) } \\
\operatorname{NEPP}^{(3)}\end{array}$ \\
\hline I daho & $\begin{array}{l}2,629,630 \\
-- \\
--\end{array}$ & $\begin{array}{l}986,127^{(11)} \\
823,529(8) \\
823,529(8)\end{array}$ & $\begin{array}{l}44.7^{(8)} \\
-- \\
--\end{array}$ & $\begin{array}{l}16.8^{(8)} \\
14.0 \\
14.0\end{array}$ & $\begin{array}{l}\text { SRI (3) } \\
\text { Miles (4) } \\
\text { NEPP (3) }\end{array}$ \\
\hline TOTAL & $\begin{array}{c}26,153,256 \\
-- \\
--\end{array}$ & $\begin{array}{l}3,218,553(71) \\
3,411,765(8) \\
3,405,882(8)\end{array}$ & $\begin{array}{c}444.6^{(8)} \\
-- \\
--\end{array}$ & $\begin{array}{l}54.7^{(8)} \\
58.0 \\
57.9\end{array}$ & $\begin{array}{l}\text { SRI (2) } \\
\text { Miles (4) } \\
\text { NEPP (3) }\end{array}$ \\
\hline
\end{tabular}




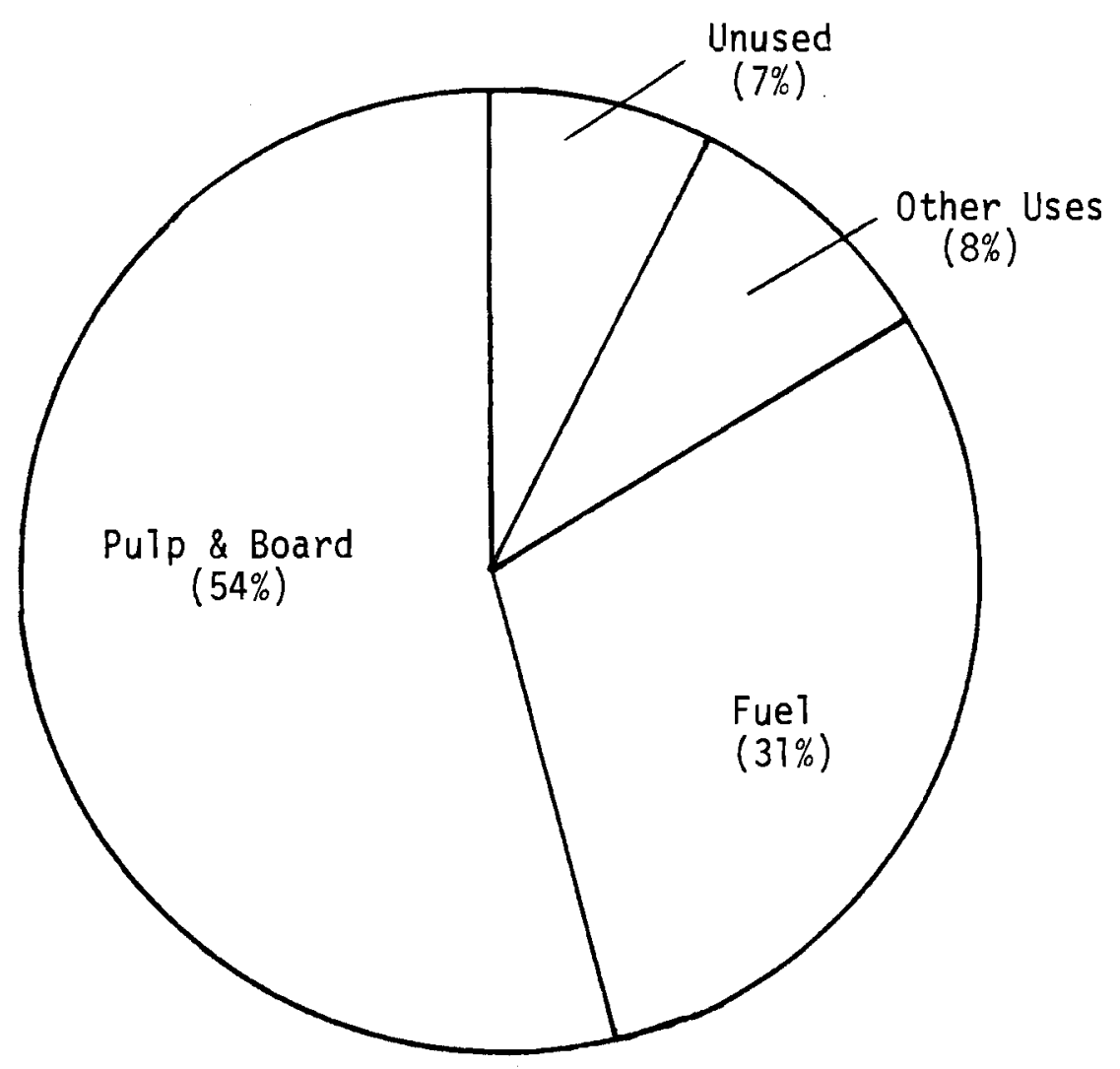

FIGURE 1. Use of Wood Mi11 Residues in Washington (1976)

TABLE 5. Use of Wood Mi11 Residues in the Northwest (Percent)

$\begin{array}{lccc} & \text { Sold } & \underline{\text { Fuel }} & \text { Wasted } \\ \text { Idaho } & 47.9 & 14.6 & 37.5 \\ \text { Oregon } & 63.1 & 28.2 & 8.7 \\ \text { Washington } & \underline{52.4} & \underline{36.0} & \underline{11.5} \\ \quad \text { Region } & 58.9 & 28.8 & 12.3\end{array}$

Source: Reference 2 . 


\subsection{AGRICULTURAL WASTES}

Agricultural wastes include crop residues and animal wastes. Of the total estimated volume of agricultural wastes in the Northwest Region, roughly 90 to 95\% is crop residues and 5 to $10 \%$ is animal wastes. As shown by Table 6 , a large variation exists among the different estimates of total available agricultural wastes. For the state of Washington, the DNR ${ }^{(5)}$ puts total agricultural wastes at 5,118,865 dry tons, while the Stanford Research Institute $(S R I)^{(2)}$ estimates $8,113,993$ dry tons, a difference of $59 \%$. However, the DNR estimates that $24 \mathrm{TBtu}\left(10^{12} \mathrm{Btu}\right)$ of this waste is available as usable energy, while SRI estimates that $111.65 \mathrm{TBtu}$, or $365 \%$ more, is available for fue 1 use.

This disparity occurs for two reasons. First, in making the conversion to heat values, SRI used a value of $7500 \mathrm{Btu} / \mathrm{lb}$ of agricultural waste, while the DNR used a value of $6500 \mathrm{Btu} / \mathrm{lb}$. The second reason for the difference has to do with the two sources' estimates of total available crop residues. Since crop residues make up the majority of agricultural wastes, differences in the estimates of crop residues, result in substantial differences in total agricultural waste estimates. The SRI estimate of total available agricultural waste includes all crop residues that are presently either wasted or returned to the soil. This is equivalent to assuming that all the crop residues can be collected and removed from the field. However, many authors argue that, depending on the specific qualities of the soil, some percentage of residue must be left in the field to maintain the nutrient content of the soil and prevent erosion. Also, crop residue is, in certain areas of the Northwest, such as the Grants Pass area of Oregon, an important component of the disease and insect control operations through seasonal field burning. Based on this argument, the DNR reduces their estimate of total crop residues by $64 \%$. This means that only $36 \%$ of the total waste can be removed from the field.

Although the difference between the SRI and DNR estimates of the percentage of crop residue that must remain on the land is great, it does not represent the full range of opinion. Indeed, the Northwest Energy Policy Project (NEPP) ${ }^{(3)}$ contends that so little of the total amount of crop residues inventoried by SRI is realistically available to be used as fuel, that, other than in specialized local circumstances, crop residues do not present energy prospects sufficient to warrant serious attention. 
TABLE 6. Agricultural Wastes (Crop and Animal)

\begin{tabular}{|c|c|c|c|c|c|}
\hline & $\begin{array}{c}\text { Annual } \\
\text { Production } \\
\text { (dry tons) }\end{array}$ & $\begin{array}{l}\text { Annual } \\
\text { Available } \\
\text { Portion } \\
\text { (dry tons) }\end{array}$ & $\begin{array}{c}\text { Total Heat } \\
\text { Content } \\
\left(10^{12} \mathrm{Btu}\right)\end{array}$ & $\begin{array}{c}\text { Available } \\
\text { Heat } \\
\text { Content } \\
\left(10^{12} \text { Btu }\right)\end{array}$ & Source \\
\hline Washington & $\begin{array}{c}5,118,865 \\
8,113,993 \\
--\end{array}$ & $\begin{array}{l}1,842,423 \\
7,443,662^{(6)} \\
8,040,000^{(7)}\end{array}$ & $\begin{array}{c}66.68 \\
121.7^{(7)} \\
\ldots\end{array}$ & $\begin{array}{l}24.0 \\
111.65^{(7)} \\
120.6\end{array}$ & $\begin{array}{l}\operatorname{DNR}^{(5)} \\
\text { SRI }^{(2)} \\
\text { Miles }\end{array}$ \\
\hline Oregon & $\begin{array}{c}3,469,199 \\
--\end{array}$ & $\begin{array}{l}3,312,870^{(5)} \\
3,426,667^{(7 !}\end{array}$ & $\begin{array}{l}52.0^{(7)} \\
--\end{array}$ & $\begin{array}{l}49.69^{(7)} \\
51.4\end{array}$ & $\begin{array}{l}\text { SRI } \\
\text { Miles } \\
(4)\end{array}$ \\
\hline Idaho & $\begin{array}{c}6,199,990 \\
-\end{array}$ & $\begin{array}{l}5,899,042^{(6)} \\
6,120,000^{(7)}\end{array}$ & $\begin{array}{l}93.0^{(7)} \\
--\end{array}$ & $\begin{array}{l}88.49^{(7)} \\
91.8\end{array}$ & $\begin{array}{l}\text { SRI }^{(2)} \\
\text { Miles }^{(4)}\end{array}$ \\
\hline TOTAL & $\begin{array}{c}17,783,182 \\
-- \\
--\end{array}$ & $\begin{array}{c}16,655,574^{(6)} \\
17,586,667^{(7)} \\
8,812,500\end{array}$ & $266.7^{(7)}$ & $\begin{array}{l}249.83^{(7)} \\
263.8 \\
141.0\end{array}$ & $\begin{array}{l}\text { SRI (2) } \\
\text { Miles (4) } \\
\text { NEPP(3) }\end{array}$ \\
\hline
\end{tabular}


In addition to crop residues, agricultural wastes include animal wastes (i.e., manure). Animal wastes are a much smaller potential energy resource than other residues. SRI estimates that 831,000 tons $(12.5 \mathrm{TBtu}$ at 7500 Btu/lb) of animal waste are collectable in the Northwest. This comprises only $5 \%$ of their total estimate of agricultural waste. Besides the relatively small quantities of animal wastes in the Northwest, two other factors may tend to constrain use of these wastes as an energy resource. First, large animal feedlots where manure could be collected in large quantities do not exist in the Northwest: Transportation of the wastes from many small sources to a central combustion or conversion facility would increase the final cost of energy from an imal wastes. Second, the high percentage of water in animal wastes makes them more suitable for conversion to fuel gas by anaerobic digestion, a process that nets fairly low energy returns. ${ }^{(3)}$

\subsection{MUNICIPAL WASTE}

Municipal waste includes solid waste (garbage) and urban sewage. As shown in Table 7 , municipal wastes comprise less than $10 \%$ of the total estimated biomass resource base in the Northwest. Thus, use of these wastes as a fuel source is likely to have a smaller impact on the overall energy picture than the use of other forms of biomass. However, two factors relating to municipal waste may tend to make use of it for energy purposes a desirable option. First, municipal waste is currently disposed of in municipal wastewater treatment plants, incinerators, and sanitary landfills. All of these disposal techniques are expensive and present serious environmental problems. By digesting or pyrolyzing municipal waste into a clean-burning fuel, a community would realize economic savings from reduced energy use and also avoid some of the expense and environmental problems associated with waste disposal. Secondly, because the areas where large quantities of municipal waste are generated are also the areas with large energy requirememts (i.e., cities), long-distance transportation of the wastes prior to conversion to energy would not be needed. However, the limited number of large population centers in the Northwest constrains the total amount of energy available from municipal waste sources. 
TABLE Z. Municipal Wastes (MSW, Sewage)

\begin{tabular}{|c|c|c|c|c|c|}
\hline & $\begin{array}{c}\text { Annual } \\
\text { Production } \\
\text { (dry tons) }\end{array}$ & $\begin{array}{l}\text { Annual } \\
\text { Available } \\
\text { Portion } \\
\text { (dry tons) }\end{array}$ & $\begin{array}{c}\text { Total Heat } \\
\text { Value } \\
\left(10^{12} \text { Btu }\right)\end{array}$ & $\begin{array}{l}\text { Available } \\
\text { Heat } \\
\text { Value } \\
\left(10^{12} \text { Btu }\right)\end{array}$ & Source \\
\hline Washington & $\begin{array}{c}1,467,381 \\
-- \\
--\end{array}$ & $\begin{array}{l}1,297,661 \\
1,187,500^{(9)} \\
1,272,000(10)\end{array}$ & $\begin{array}{c}22.22 \\
-- \\
--\end{array}$ & $\begin{array}{l}19.65 \\
19.0 \\
20.29(10)\end{array}$ & $\begin{array}{l}\text { DNR }^{(5)} \\
\text { Miles (2) } \\
\text { NEPP(3) }\end{array}$ \\
\hline Oregon & -- & $\begin{array}{c}750,000^{(3)} \\
\cdot 727,000^{(70)}\end{array}$ & -- & $\begin{array}{l}12.0 \\
11.6(10)\end{array}$ & $\begin{array}{l}\text { Miles }{ }^{(4)} \\
\operatorname{NEPP}(3)\end{array}$ \\
\hline Idaho & -- & $\begin{array}{l}250,000^{(9)} \\
183,000^{(10)}\end{array}$ & -- & $\begin{array}{l}4.0 \\
2.9 g(10)\end{array}$ & $\begin{array}{l}\text { Miles (4) } \\
\text { NePp (3) }\end{array}$ \\
\hline TOTAL & -- & $\begin{array}{l}2,187,500^{(a)} \\
2,182,000\end{array}$ & -- & $\begin{array}{l}35.0 \\
34.9\end{array}$ & $\begin{array}{l}\text { Miles (4) } \\
\text { NEPP (3) }\end{array}$ \\
\hline
\end{tabular}




\subsection{CAVEATS}

Interpretation of the previously discussed estimates of the biomass resource base in the Northwest is subject to several caveats. First and foremost, it must be remembered that these estimates refer only to existing amounts of biomass that are potentially available for use as fuel. The amounts that will be actually available in the future depend on numerous technical, economic, and institutional issues. The following sections in this paper present a preliminary analysis of some of the major issues that may affect biomass availability. A complete analysis of these issues is a task that requires a great deal of additional work that is beyond the scope of this study.

The estimates of biomass availability are also open to some technical uncertainties. As noted above and also shown in Table 8 , some controversy exists concerning the actual heat content of various forms of biomass. When multiplied over a large amount of biomass, differences in the assumed conversion factors have substantial effect on the overall estimate of energy available from biomass. Whether a technical dispute or a matter of definition this issue requires resolution. Also, as noted in the section on agricultural wastes, a great deal of disagreement exists over the amount of crop residues that can be safely removed from the soil. Since the range of dispute on this topic is so wide that some estimates put agricultural wastes as the single largest source of biomass energy and others regard them as insignificant, this is an area that needs further study. Similar disagreement concerning the nutrient depletion and erosion potential from removal of forest residues exists, although to a lesser extent, and also requires more study.

Finally, characterization of other physical limitations to biomass collection is necessary. This includes definition of the minimum size of collectable forest residue, whether or not roots are likely to become collectable and at what cost, clarification of the percentage of land on which collection of forest residues is impractical due to ruggedness of terrain, and a matching of the sites of biomass availability with the sites of utilization to estimate the amounts of biomass that are available at reasonable transportation costs. Resolution of these questions would greatly improve the realism of the estimates of biomass availability in the Northwest. 
TABLE 8: Conversion Factors and Heat Values

\begin{tabular}{|c|c|c|}
\hline Fue $]$ & Btu/1b-Dry & Source \\
\hline Hardwood (dry) & 7,947 & $\mathrm{DNR}^{(5)}$ \\
\hline Softwood (dry) & 8,800 & DNR \\
\hline Softwood Bark & 9,200 & DNR \\
\hline Agricultural Waste & 6,500 & DNR \\
\hline \multirow[t]{2}{*}{ Crop Residue } & 8,000 & NEPP $(3)$ \\
\hline & 7,500 & Miles $(4)$ \\
\hline \multirow[t]{2}{*}{ Animal Waste } & 8,750 & NEPP \\
\hline & 6,500 & Miles \\
\hline Wood Residue & 8,500 & NEPP \\
\hline Logging Residue & 8,500 & Miles \\
\hline $\begin{array}{l}\text { Sawmill Residue } \\
\text { (shavings, bark, sawdust) }\end{array}$ & 8,500 & Miles \\
\hline \multirow[t]{2}{*}{ Municipal Solid Waste } & 8,000 & NEPP \\
\hline & 5,000 & Miles \\
\hline Sewage & 7,250 & NEPP \\
\hline
\end{tabular}




\subsection{IMPACTS OF FOREST RESIDUE UTILIZATION IN THE NORTHWEST}

As shown in Table 2, forest residues and agricultural wastes comprise the majority of the potential biomass resource in the Northwest Region. Utilizing the two resources for fuel requires markedly different conversion technologies and collection systems. Also, the actors involved in using agricultural wastes are different from those that would be involved in using forest residues. These differences make an impact assessment of both energy sources impossible in this small study. Because of the importance of the wood products industry to the Northwest economy, their wide-ranging potential impacts, and the fact that forest residues are nearer to widespread use as an energy resource than agricultural wastes, the impacts of forest residue utilization were chosen for focus in this portion of the study.

Several actors will play a role in the development of the forest residue energy resource. The wood products industry most likely will be involved in the collection and distribution of forest residues. Also, the wood products industry presentiy uses a good deal of wood residue, in the form of mill wastes, for fuel, and will most likely use even more in the future as energy prices rise. The federal, state, and local land management agencies will have a role in balancing the use of the public forestlands among lumber, energy, recreation, wildlife, and wilderness uses. The utilities could be involved if they decide to burn residues in wood-burning power plants. Commercial and industrial firms could be involved in using residues for space heating and/or cogeneration. Homeowners have already become significantly involved in the residue situation by their increased cutting of firewood.

The interplay between these and other parties-at-interest will result in a variety of environmental, socioeconomic, and institutional impacts. This study has attempted to identify the major potential impacts by reviewing the literature and contacting individuals involved in different aspects of the biomass energy area. The spectrum of issues that arose out of this effort is summarized in the Appendix. The outline in the Appendix gives a sense of the breadth of impacts that may arise as a result of using forest residues as a source of energy. Clearly, in a study of this size, detailed analysis of all the issues surrounding forest residue energy is not feasible. Instead, an effort has been 
made to highlight particularly important issues and perform a preliminary analysis of each issue. However, much additional study is required for a complete understanding of the issues surrounding the utilization of forest residues for fue 1 .

\subsection{COMPETING END USES}

The amount of logging residue left in the forest and the wood residue that remains unused at the mills is a direct function of the market demand for woodproducts. The value of the forest industry's products influences the residue available for fuel in two ways. First, as the market for wood products fluctuates the amount of available residue from logging and mill operations also fluctuates. Second, the increasing value of wood products can divert material previously considered economically or technically unusable into existing or new product lines.

When an area is logged, only that portion of the total amount of wood available that can be economically transported and converted is taken. The uneconomical wood is left in the forest and is generally collected into slash piles for burning. When the prices for pulp chips are high, the amount of logging residue left in the forest is significantly reduced because the higher chip prices make it economical to remove unmerchantable or "cull" logs and smaller limbs for chipping. The portion of cull logs and chips not suitable as pulp chips, but already transported to the mill, can be used for fuel. This is referred to as hogged fuel. In this manner, the pulp market has subsidized the collection of a portion of the residues for fuel.

When the pulp and paper market is in a boom period, their demand for chips can significantly reduce the amount of material for hogged fuel. Since the use of wood residues for fuel is usually the lowest valued use, it is diverted from the use as a fuel whenever it can be used for material products.

Many people feel that market fluctuations influence wood fuel supply to such a degree that market conditions are more important in determining the availability of wood fuel than is the total inventories volume of mill and logging residue. (15) When lumber is not in demand and the mills are shut down, as has occurred in 1980 in the Northwest, the supply of mill residue for pulp chips and fuel is lost. The manufacturers of insulation board, hardboard 
and particle board, who depend almost entirely on the wood residue from timberbased manufacturing plants, also lose their source of raw material. (17) Although the slump in lumber sales may also affect the demand for wood product boards and thereby reduce their need for mill residue, this is not the case for the pulp and paper industry. For example, in 1980 the pulp and paper mills were in full operation and their chip requirements were as high or higher than ever. The loss of the mill residue supply forced the pulp industry to do much more direct contract logging for trees of pulp-chip quality, the material previously considered useful only for wood fuel. (18) The supply of wood for fuel in the period of economic slowdown for the lumber products sector is greatly reduced by the loss of mill residue and logging slash pile material. And the residue material that is available is strongly sought after by the other operating wood product industries, consequently driving the value of the material up to a point where it becomes uneconomical to use it for fuel.

Competition in the future for logging and mill residue will be intense within the forest industries. There will be greater use of wood fiber for both existing and newly developed products. $(14,16)$ The use of residue in board products is expected nationally to double over the next twenty years. (17) The pulp and paper industry is also anticipated to expand over the next twenty years to a level that could potentially utilize all the recovered logging and mill residues. (17) This resource demand is expected to result in greater use of precommercial thinnings, tree tops, tree butts, and currently unused species. (16) However, this intensive use can profitably occur only at higher product prices than now exist. An indication of the increasing value of the residue material due to industry supply and demand and inflationary factors can be seen in the price paid for chips and hogged fuel in Oregon in 1971 and 1980. In 1971, mill residue shavings used for pulp chips sold for about $\$ 18$ per dry ton delivered to the pulpmi11. (17) In 1980, the price was $\$ 45$ per dry ton of pulp chips. (15) In the same period, the price of residue used for fuel (logged fuel) increased from less than $\$ 6.50$ per dry ton to $\$ 15$ per dry ton. $(15,17)$ Since the Consumer Price Index approximately doubled over this period, these increases represent average annual inflation rates of between 2 and $3 \%$ above general inflation. The value of export chips and cull logs in 1980 can also be noted in Table 9. 
TABLE 9: Volume and Value of Pulp Material, Export Chips, and Hogged Fuel for Oregon -1978 .

Putp

Chips \& Residues

9.2

45

Cu11 Logs

1.3

51

Tota1

$\overline{10.5}$

$\frac{51}{46}$

Export Chips

2.6

43

Hogged Fue1

4.3

15

Source: Reference 15 
Despite the increasing demand for wood residues for materials uses, many people feel that sufficient residues will be available in the future to provide a major source of energy in the Northwest. However, the fluctuations in availability of wood residues may make it difficult for large-scale energy conversion facilities, such as wood-burning electric plants and methanol or ammonia plants, to obtain long-term supply contracts. This may tend to discourage use of wood residues in large-scale facilities and lead to the primary use of residues occurring inside the wood products industry and residential sector, where discontinuities of supply are not a major problem. A thorough analys is of the competing markets for wood residues is important to achieving a balanced mix of uses for wood residues in the Pacific Northwest.

\subsection{FOREST MANAGEMENT POLICIES}

The USDA Forest Service has responsibility for managing the National For est System, conducting forestry research, and providing cooperative services for state and private landowners. The manner in which the Forest Service handles these duties is potentially an important factor influencing the degree to which forest residues are utilized as an energy source. Forest Service policies are a particularly important factor in the forestry picture in the Northwest Region (Region $X$ ), due to the high percentage of forest land that is federally administered in this region. As shown in Table $1,66 \%$ of the commercial forest land in Region $X$ is federally administered. In Alaska, most of the federal land is administered by the Bureau of Land Management, whereas most of the commercial timberland falls under the U.S. Forest Service jurisdiction (see Table 1). In the other three states, where most of the commercial timber in the region is produced, the majority of both the federal land and commercial timberland is administered by the Forest Service. In addition, the forest management policies of the states tend to be modeled after those of the Forest Service. Thus, this section concentrates primarily on the role of the Forest Service in the development of forest residues as an energy resource.

The Forest Service has a wider scope of concern with regard to the National Forests than simply timber production. The Forest and Rangeland Renewable Resource Planning Act of 1974 directs the Secretary of Agriculture to periodically assess the renewable resource situation. These assessments consider 
competing demands on the forest and rangeland and proposed alternative Forest Service programs for dealing with these demands. The competing uses for forestland include timber, water, minerals, wildlife, camping, hunting, fishing, and nature study. According to the 1980 assessment by the Forest Service, demand for all these commodities is rising and is projected to continue to rise faster than supplies. (19) This implies increased prices of stumpage and timber products, relative to the general price level, as well as potential shortages of available recreational opportunities. For this reason, the Forest Service is faced with difficult multiple-use questions regarding the National Forests. No obvious solution for mediating between these competing claims on the forest lands exists.

The decision by the Forest Service on RARE II $(20,21,22,23)$ and any other proposals involving the withdrawal of lands from timber production for other purposes may have an impact on the availability of wood residues for use as fuel. If these withdrawals are made and constrain the timber supply for woodproducts, the value of the available wood residues for use in production of wood products, such as paper and particleboard, may increase. This could make use of this residue as fuel an uneconomic prospect.

A second Forest Service policy that bears upon the collection of biomass is the requirement that the loggers collect and pile the slash, or yarded unmercantable material (YUM), near roads to facilitate disposal. This is done to decrease the risk of fire and insect-borne disease and also for aesthetic reasons. Generally, these slash piles are then burned. However, since the effort to collect the slash has already been expended, it would be much cheaper for the loggers or an outside group to remove the slash from the forest. Thus, this Forest Service policy tends to enhance the economics of slash collection and removal from the logger's perspective. Similar policies are in effect on state and Bureau of Land Management land.

One final area in which the U.S. Forest Service has an impact on the use of wood residues as fuel is their research programs. The Forest Service is conducting studies concerning the resource economics of biomass for energy and also technical studies involving the conversion processes for biomass, such as production of methanol (wood alcohol) from wood. (19) These studies are particularly important because the vast communications network which the Forest 
Service maintains both with private logging companies and state organizations will enable wide dispersal of the results.

\subsection{INJURIES AND DEATHS FROM RESIDUE COLLECTION}

This section presents an analys is that attempts to quantify the potential deaths, injuries, and man-days lost from collecting forest residues. In this manner, the worker safety aspects of woody biomass can be made with those of other energy sources. This study compares woody biomass to coal in terms of injuries, deaths, and lost workdays per $10^{12} \mathrm{Btu}$ of energy produced. Forest residues are shown to be a much more hazardous source of energy than coal.

Several sources were used to obtain information on the deaths, injuries and man-days lost in association with the collection of woody biomass. The appoach used was to take data from the State of Washington Department of Labor and Industries (DLI) on deaths and injuries from Washington logging camp and logging contractors operations. ${ }^{(24)}$ These data refer to all operations involved in logging a stand of timber. Since not a 11 of these operations would be needed to collect forest residues, the following was used in conjunction with the DLI data:

- The tota 1 wood harvested in the State of Washington in 1976 and 1978 was 10.5 and 11.6 billion board feet using the Scribner log rule for expressing volume of logs in board feet (1976 and 1978 Washington Mill Survey). (13)

- To convert board feet to Btu:

$$
\begin{aligned}
1 \text { board foot } & =\left(\frac{1 \mathrm{ft}^{3}}{12 \mathrm{~b} . \mathrm{f} .}\right)\left(\frac{1.137 \text { tons }}{80.6 \mathrm{ft}^{3}}\right)\left(\frac{2000 \mathrm{lb}}{1 \mathrm{ton}}\right)\left(\frac{8500 \mathrm{lb}}{1 \mathrm{bb}}\right) \\
& =20,000 \mathrm{Btu}=0.02 \mathrm{MBtu}
\end{aligned}
$$

Assuming,

$$
\begin{aligned}
& 80.6 \mathrm{ft}^{3}=1.137 \text { tons (dry weight) } \\
& 12 \text { board feet }=1 \mathrm{ft}^{3} \\
& 1 \text { ton }=2000 \mathrm{lb} \\
& 1 \mathrm{lb}=8500 \mathrm{Btu}
\end{aligned}
$$


The Washington Mi11 Surveys for 1976 and 1978 were used for data on the total wood consumed by the industry including export, plywood production, lumber production and pulp and board production. (13) The figures used for this analysis are the sum of the wood consumed by the wood products industry plus exported wood minus imported wood. This information is the best approximation of the total wood harvesting activity that is comparable to the cases identified by DLI. Table 10 shows the conversion of the wood harvested to Btu's and comparison with the DLI data for injuries, deaths, and lost workdays. The ratio of injuries, deaths, and lost workdays are computed and averaged for the two years of available data. Note that these ratios are applicable to woody biomass collection when the whole tree is harvested, as in plantations.

TABLE 10. Injuries, Deaths, and Lost Workdays From Commercial Wood Harvesting

\begin{tabular}{|c|c|c|c|c|c|c|c|c|}
\hline & & & $\begin{array}{l}\text { Ratic } \\
10^{9} \\
\end{array}$ & $\begin{array}{l}\text { Per } \\
\mathrm{ft} \\
\end{array}$ & & $\begin{array}{r}\text { Ratic } \\
10^{12} \\
\end{array}$ & $\begin{array}{l}\text { Per } \\
\text { Btu } \\
\end{array}$ & \\
\hline & $\begin{array}{r}10^{9} \\
\text { bd } \mathrm{ft} \\
\end{array}$ & $\begin{array}{c}10^{1 L} \text { Btu } \\
\text { Equi- } \\
\text { valent } \\
\end{array}$ & Deaths & $\begin{array}{l}\text { Lost } \\
\text { Work- } \\
\text { days } \\
\end{array}$ & Injuries & Deaths & $\begin{array}{l}\text { Lost } \\
\text { Work - } \\
\text { days }\end{array}$ & Injuries \\
\hline 1976 & 10.5 & 210 & 2.4 & 2,942 & 372 & 0.12 & 147.1 & 18.6 \\
\hline 1978 & 11.6 & 232 & 1.4 & 2,122 & 216 & $\underline{0.07}$ & 106.1 & 10.8 \\
\hline Ave. & 11.0 & 221 & 1.9 & 2,532 & 294 & 0.09 & 126.6 & 14.7 \\
\hline
\end{tabular}

Residue removal is a different operation and therefore more assumptions were needed for this kind of biomass collection. Forest, residue removal begins with the biomass already on the ground. Thus, those injuries related to felling and bucking the tree should not be included. A comprehensive study on Worker Safety in Logging Operations ${ }^{(25)}$ indicated that about $35 \%$ of all injuries are incurred by "fallers and buckers." The second consideration is that residue removal from a given acre takes as long as the initial tree removal. This is an important assumption based on some anecdotal evidence and depends on the manner in which the residue is collected. It is important because as $\mathrm{Hall}(26)$ reports, the ratio of timber volume removal to logging residues is approximately 8 in the Pacific Coast Forests. Thus, the ratios per 
$10^{12}$ Btu given above must be reduced by 0.65 to account for the fewer activities and increased by a factor of 8 to account for the increased labor per Btu removed that is required for residue removal. The calculated ratios for residue removal are as follows:

$$
\begin{aligned}
\text { Deaths } & =0.47 \text { per } 10^{12} \mathrm{Btu} \\
\text { Injuries } & =76.5 \text { per } 10^{12} \mathrm{Btu} \\
\text { Lost Workdays } & =658.3 \text { per } 10^{12} \mathrm{Btu}
\end{aligned}
$$

To give some idea of how these ratios compare to those for conventional energy sources, a study on morbidity and mortality in the coal industry was examined. (27) This study reports deaths, injuries and man-days lost in mining and transporting coal to fuel a $1000 \mathrm{MW}$ electric plant for one year. Using the assumptions of a heat efficiency of 8500 Btu per KWh and a capacity factor of $67 \%$, these ratios can be converted to injuries and deaths per $10^{12} \mathrm{Btu}$. The following table displays the results of this conversion.

TABLE 11. Injuries, Deaths, and Lost Workdays from Coal Mining and Transportation

\begin{tabular}{cl} 
Ratio per & Ratio per \\
1000 MWe Plant & $10^{12}$ Btu \\
\hline
\end{tabular}

$\begin{array}{lcc}\text { Coal Mining } & & \\ \text { Deaths } & 0.5 & 0.01 \\ \text { Injuries } & \mathrm{N} / \mathrm{A} & \mathrm{N} / \mathrm{A} \\ \text { Man-Days Lost } & 2880 & 57.7 \\ \text { Coal Transportation } & & \\ \text { Deaths } & 1.3 & 0.026 \\ \text { Injuries } & 11.48 & 0.23 \\ \text { Man-Days Lost } & \mathrm{N} / \mathrm{A} & \mathrm{N} / \mathrm{A}\end{array}$

These numbers make no consideration of the health effects of pneumoconiosis, or "black lung disease," among miners. However, the fact that the deaths from collecting forest residues are times higher than the combined deaths from coal mining and transportation clearly calls attention to the importance of safety as a public policy issue in relation to woody biomass energy. 
These figures are based on data from professional loggers. The weekend woodcutter will probably suffer higher injury levels, due to inexperience with equipment and lack of knowledge of the hazards. However, as time goes on, it is possible that those who remain interested in biomass collection will have become much more knowledgable, experienced and safety-concious.

This preliminary investigation of the health and safety aspects of forest residue collection is by no means the definitive study. In particular, the assumption that it takes as long to collect the residue from an area as it does to log off the merchantable timber is not strongly supported. If collection of residues could be done more quickly than this, or with smaller equipment or fewer men, these estimates might be reduced by as much as an order of magnitude. This might be best accomplished by bringing the whole tree up the slope and bucking it on the landing instead of cutting off branches at the bottom of the hill and then returning to pick up the slash. Yarding the whole tree would reduce both the cost of collecting slash and the time spent in the woods. Whole-tree yarding should be more and more feasible as more logging is done of second growth forests, due to the smaller size of the trees. The reduced time in the woods should result in fewer injuries. However, it should be noted that a reduction of a factor of ten would still leave forest residues at about the level of coal in terms of hazardousness.

\subsection{BIOMASS/CONVENTIONAL FUELS AIR EMISSIONS TRADEOFFS}

The use of biomass material as an energy resource in the Northwest is expected to increase in the coming years. Presently, biomass supplies about $10 \%$ of the total energy demand for the region (5\% from industrial mill residue use and 5\% from residential wood burning). But, as the cost of conventional fuels increases, it is anticipated that biomass will begin to displace these fuels to an even greater degree than is occuring today. $(28,29,30)$ One of the major concerns associated with this fuel switching is the potential increase in particulate emissions. To determine whether this is a possible problem, and if so, how extensive it might become, an assessment of the air emissions tradeoffs from the displacement of conventional fuels by biomass was undertaken. One of the major considerations of such an assessment was the amount of biomass material burned. 
The eventual use of any form of biomass material as a fuel, be it mill residue, forest residue, agricultural residue or municipal waste, will depend on numerous technical, social, environmental and economic factors. Issues such as the cost of conventional fuels, biomass collection constraints, competing end uses for the material and soil nutrient requirements will tend to limit the actual amount of biomass used as a fuel source to some portion of its potential maximum. Attempting to predict the actual quantities of biomass to be consumed in the future as fue 1 in the Northwest is next to impossible. Consequently, the air emissions tradeoffs assessment was based on the maximum potential utilization of available biomass for fuel. The following four sectors are considered most likely to consume the majority of the material: the wood products sector, the food and kindred products sector, the electric utility sector and the residential sector. Natural gas and $0 i 1$ are assumed to be the primary conventional industrial fuels displaced by biomass. In the utility sector, coal would be displaced. The use of wood for residential space heating would displace natural gas, $0 i 1$ and to some degree, electricity. This reduction in the residential sector demand for electricity would be expected to result in a further displacement of coal by the electric utilities. Although it is recognized that these are gross assumptions and that constraints will limit biomass fuel use below the assessed levels, the results of this activity are useful for two reasons. First, they provide a basis for understanding how the displacement of conventional fuel with biomass could affect the Northwest's air quality. Second, they indicate a direction for future efforts in this area for more site, resource and/or user sector specific air emission tradeoff investigations.

\subsubsection{Potential Biomass Fuel}

Mill and Logging Residue

The Northwest wood products industry generates an enormous quantity of residue in its manufacturing and logging operations. An estimated 25 million tons (dry weight) of mill residue and $10 \mathrm{million}$ tons (dry weight) of logging residue are generated annualiy in Washington, Oregon and Idaho (see Tables 3 and 4). $(5,2,3,31,32,33)$ Approximately $93 \%$ of the mill residue is already being utilized for such purposes as raw material for the pulp and board industry, fue 1 for the wood products industry, gardening and landscaping mulch and animal bedding. $(32,33)$ The remaining $7 \%$ is either buried, left in the forest 
(in the case of some portable mills) or burned (but not as a fuel). Logging residue though, until recently, has not been used in the Northwest to any major degree. The material remaining after logging operations was generally either allowed to lay as felled in the forest or yarded and burned. Since the mid-tolate seventies however, this logging residue has been used significantly by the residential sector. $(34,35)$ As home heating costs have increased over the past few years, the residential sector has begun to use woodstoves and fireplaces to reduce annual winter heating bills. The residential sector in 1980 consumed an average of two cords of wood per year for each wood-burning appliance in the Northwest. ${ }^{(35)}$ This consumption translates into 3 million cords, or approximately 4 million tons (dry weight), a year. Although there is little documentation on the actual sources of this wood, roughly $75 \%$ of the material is assumed to come from logging residue. The remaining $25 \%$ is comprised of noncommercial timber, dead trees and wood from timber-stand thinning operations. Of the 10 million tons of logging residue annually generated, some 7 million tons remained unused as of 1980 .

Projections of the Northwest wood products industry indicate that little if any growth in mill or logging residue will occur to the year $2000 .(36,37)$ The 11.8 million tons of mill and logging residue $(1.8 \mathrm{million}$ tons of mill residue and about 10 million tons of logging residue) annually available for fuel as of the mid-to-late seventies is not expected to increase in the coming years (it, in fact, may decrease due to the decline of old growth timber operations). Consequently, 11.8 million tons of residue is also assumed to be the maximum available quantity of fuel material from mill and logging operations in the year 2000, providing 192 TBtu of potential energy.

\section{Agricultural Wastes}

Agricultural wastes consist of crop residue and animal wastes. In the Northwest, crop residues constitutes the vast majority of all agricultural wastes. Animal wastes constitute only $5 \%$ of the total agricultural waste estimates. (2) A detailed assessment of the 1978 to 1980 crop production and residue generation for each county in Washington, Oregon and Idaho identified 183 TBtu of potential energy. (38) SRI estimates that 12.5 TBtu of animal waste is annually available in the Northwest. Wheat and barley residue makes up $93 \%$ of the total estimated agricultural crop residue. The amount of this 
residue that could actually be collected remains debatable. Many views exist as to the amount of material that must remain on the soil for nutritional and soil stabilization purposes. For the purposes of the air emissions tradeoff assessment, the maximum amount of agricultural waste that could be used was assumed to be at most $10 \%$ of the total available material. Also, the agricultural sector was assumed to experience an annual growth rate of $2 \%$. The amount of energy from agricultural waste in the year 2000 was therefore assumed to be 227.1 TBtu.

\section{Municipal Waste}

The total amount of municipal waste produced each year in the Northwest region is estimated to be 2.2 million tons. $(3,4)$ Projections of population growth within the region by the Bonneville Power Administration indicate an average annual increase of slightly greater than $2 \%$ from 1980 to $2000 .(39,40,41)$ If, as assumed, the quantity of municipal waste per capita remains constant, then by the year 2000, 3 million tons per year could be available as potential fuel. The use of all $3 \mathrm{million}$ tons as fuel, representing the maximum potential use of this material, could provide $48 \mathrm{TBtu}$ of heat.

In total, biomass material has an estimated maximum potential of providing 290 TBtu of heat energy in the year 2000. As presented in Table 12, most of the material, 45\%, is found in Washington State. Oregon is estimated to have $41 \%$ of the available biomass material, whereas Idaho has $14 \%$. The majority of the information on wood products, and agricultural and municipal waste was based on studies of the situation in the mid-to-late 1970's. As previously mentioned, the residential sector used only a minimal amount of logging residue in the mid seventies. All estimates of the maximum potential amount of unused biomass material available as a fuel source in 2000 are based on the situation in the mid to late 1970's. As Table 12 shows, all ten million tons, 169 TBtu, of logging residue is considered unused and available for conventional fue 1 displacement in 2000. Almost 2 million tons of mill residue ( $31.3 \mathrm{TBtu}), 1.8$ million tons of agricultural waste (27.1 TBtu), $3.3 \mathrm{million}$ tons of municipal waste (48 TBtu), and some 900 million tons of noncommercial, diseased and other material (14.7 TBtu) are assumed available for burning in the year 2000. This maximum potential heat value of 290 TBtu from the biomass material is slightly 
TABLE 12. Maximum Potential Quantities of Northwest Biomass Annually Available as Fuel - Yr. 2000

\begin{tabular}{|c|c|c|c|c|}
\hline & \multicolumn{4}{|c|}{ (Thousand Tons, Dry Weight) } \\
\hline & Washington & Oregon & Idaho & $\begin{array}{l}\text { Pacific Northwest } \\
\text { Region } \\
\end{array}$ \\
\hline Mill Residue & 485 & 530 & 824 & 1,840 \\
\hline Logging Residue & 4,400 & 4,770 & 700 & 9,900 \\
\hline Agricultural Wastes & 770 & 370 & 660 & 1,800 \\
\hline Municipal Wastes & 1,800 & 1,100 & 350 & 3,300 \\
\hline $\begin{array}{l}\text { Noncommercial, } \\
\text { Diseased } \\
\text { Material }\end{array}$ & -- & -- & -- & 870 \\
\hline
\end{tabular}

(a) Residential Firewood Materials.

greater than the TASE Base Case ( 6 Quads Scenario) projections for the Northwest region. The DOE Base Case Scenario indicates that 217 TBtu of energy could be supplied by biomass in the Northwest in the year 2000. The 14 quad scenario projects 410 TBtu of energy from Northwest biomass in the year 2000 . To obtain $290 \mathrm{TBtu}$, it was necessary to assume that all available biomass material could and would be burned. This level of consumption is extremely unrealistic due to numerous economic and technical and social factors. Even obtaining $217 \mathrm{TBtu}$, as the 6 quad scenario suggests, would be unrealistic for the Northwest by the year 2000. To achieve $410 \mathrm{TBtu}$, not only would all the identified available residue and waste in the region have to be consumed, but almost $60 \%$ of the physically available agricultural waste would need to be burned.

\subsubsection{Conventional Fuel Displacement}

By the year 2000 biomass could potentially displace a significant quantity of conventional oil, gas and/or coal in the Northwest. Four specific sectors are anticipated to utilize the majority of the biomass as a fuel: the residential sector, the wood products industrial sector, the food and kindred products sector and the electric utility sector. The amount of biomass each sector could annually consume in 2000 is presented in Table 13. 
TABLE 13. Biomass Input Energy and Conventional Energy Displace by Biomass - Yr 2000 (1012 Btu/yr)

\begin{tabular}{|c|c|c|c|c|c|c|c|c|c|c|c|c|c|c|c|}
\hline & \multicolumn{8}{|c|}{ BIOMASS } & \multicolumn{7}{|c|}{ CONVENT IONAL } \\
\hline & 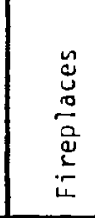 & 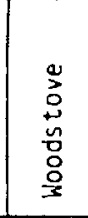 & 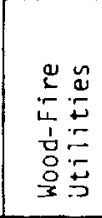 & 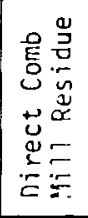 & 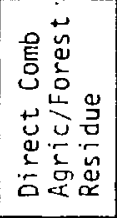 & 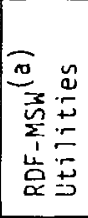 & 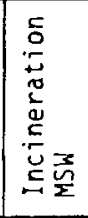 & 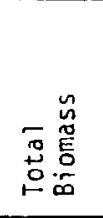 & 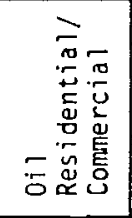 & 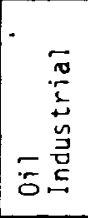 & 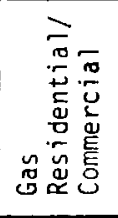 & 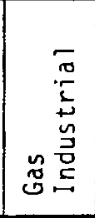 & 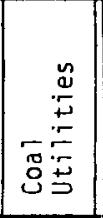 & 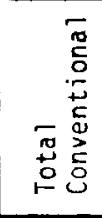 & 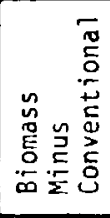 \\
\hline vashington & 29.9 & 43.6 & 18.8 & 8.2 & 11.6 & 13.5 & 13.5 & 139.1 & 13.5 & 6.0 & 13.5 & 27.4 & 56.2 & 116.6 & 22.5 \\
\hline oregon & 19.9 & 29.0 & 20.0 & 9.0 & 5.6 & 8.5 & 8.5 & 100.5 & 9.0 & 5.0 & 9.0 & 18.1 & 44.1 & 85.2 & 15.3 \\
\hline Idano & 7.8 & 11.4 & 14.8 & 2.5 & 9.9 & 2.0 & 2.0 & 50.4 & 3.5 & 1.0 & 3.5 & 13.4 & 22.9 & 44.3 & 6.1 \\
\hline $\begin{array}{l}\text { iorthwest } \\
\text { Region }\end{array}$ & 57.6 & 84.0 & 53.6 & 19.7 & 27.1 & 24.0 & 24.0 & 290.0 & 26.0 & 12.0 & 26.0 & 58.9 & 123.2 & 246.1 & 43.9 \\
\hline
\end{tabular}

(a) Refuse Derived Fuel - Municipal Solid Waste 


\section{Residential Sector}

The residential use of wood for space heating is projected to increase from the minimal levels in the mid seventies to about 6 million cords a year by 2000 . (42) This amount of wood has a potential heat value of 141.6 TBtu. As of 1974, the residential sector used 281 TBtu of oil, natural gas, electricity, coal and liquid petroleum gas. (43) This annual energy consumption is forecast to be 465 TBtu by the turn of the century. ${ }^{(44)}$ Wood could displace up to about $30 \%$ of the residential demand for conventional fuels in 2000 . Due to the relatively low electric power rates in the Northwest, it is expected that wood fuel would tend to primarily replace oil and gas use. Electricity would be displaced only after all oil and gas related demand was met. Oregon is the only Northwest state where there is sufficient potential wood fuel to displace all residential oil and gas fuels and impact electricity demand.

As seen in Table 13, the residential sector is expected to burn about $60 \%$ of the 141 TBtu available in woodstoves. The remaining $40 \%$ would be burned in fireplaces. The conversion efficiency of woodstoves and fireplaces is about $50 \%$ and $10 \%$, respectively. The impact on the amount of particulates emitted per trillion Btu of end-use heat is significantly different for the two woodburning systems. Woodstoves produce 1307 tons of particulates per TBtu, while fireplaces produce 6067 tons/TBtu. Table 14 lists the particulates emission factors for all biomass and conventional fuel systems being assessed.

\section{Wood Products Industrial Sector}

The Northwest wood products industry is not expected to increase in size or residue production between now and the year 2000. The complete use of a 11 1.8 million tons of presently unused mill residue would provide $31.2 \mathrm{TBtu}$. If the wood products industry used this material as a fuel source to displace only $0 i 1$ and gas requirements, 680,000 tons of residue, or $11.5 \mathrm{TBtu}$, would remain. $(45,46)$ This is because in Idaho there is a significant quantity of mill residue unused and a relative small demand by the industry for $0 i 1$ and gas. In Washington, almost a 11 oil and gas used by the industry could be displaced by mill residue. However, in Oregon mill residue could only meet $66 \%$ of the $\mathrm{D} i \mathrm{l}$ and gas requirements. The remaining $11.5 \mathrm{TBtu}$ of mil1 residue energy situated in Idaho could potentially be used for electric power generation purposes, thereby reducing the need for additional coal-fired electric power generation to meet the Northwest's electric demands. 
TABLE 14. Direct Combustion Processes - Particulate Emission Factors and Conversion Efficiencies

\begin{tabular}{|c|c|c|}
\hline Combustion Processes & $\begin{array}{c}\text { Particulate } \\
\text { Emission Factor } \\
\text { (tons of Particulates } / 10^{12} \\
\text { Btu End-Use Energy) } \\
\end{array}$ & $\begin{array}{c}\text { Conversion } \\
\text { Efficiency (\%) }\end{array}$ \\
\hline \multicolumn{3}{|l|}{ Biomass Fuels } \\
\hline Fireplace & $6067^{(a)}$ & 10 \\
\hline Woodstove & $1307^{(a)}$ & 50 \\
\hline Wood-Fired Utility Power Plant & $23^{(b)}$ & 34 \\
\hline $\begin{array}{l}\text { Direct Combustion of Mill } \\
\text { Residue }\end{array}$ & $150^{(c)}$ & 62 \\
\hline $\begin{array}{l}\text { Direct Combustion of Agricultural } \\
\text { and Logging Residue }\end{array}$ & $354^{(d)}$ & 62 \\
\hline $\begin{array}{l}\text { Refuse Derived Fue } 1 \text { - Municipal } \\
\text { Solid Waste (RDF-MSW) Fired } \\
\text { Utility Power Plant }\end{array}$ & $214^{(c)}$ & 34 \\
\hline $\begin{array}{l}\text { Municipal Solid Waste (MSW) } \\
\text { Incineration }\end{array}$ & $115^{(c)}$ & 62 \\
\hline \multicolumn{3}{|l|}{ Conventional Fuels } \\
\hline $\begin{array}{l}0 \text { il Combustion - Residential/ } \\
\text { Commercial }\end{array}$ & 44 & 60 \\
\hline 0 il Combustion - Industrial & 63 & 62 \\
\hline $\begin{array}{l}\text { Natural Gas Combustion - } \\
\text { Residential/Commercial }\end{array}$ & 5 & 60 \\
\hline $\begin{array}{l}\text { Natural Gas Combustion - } \\
\text { Industrial }\end{array}$ & 5 & 62 \\
\hline Coal-Fired Utility Power Plants & 23 & 34 \\
\hline $\begin{array}{l}\text { (a) Uncontrolled emissions. } \\
\text { (b) } 99 \% \text { controlled emissions. } \\
\text { (c) } 95 \% \text { controlled emissions. } \\
\text { (d) } 75 \% \text { controlled emissions. }\end{array}$ & & \\
\hline
\end{tabular}


The conversion efficiencies and particulate emission factors for direct combustion of mill residue, industrial oil and industrial gas are presented in Table 14 .

\section{Electric Utility Sector}

To meet projected demands for electric power, the Northwest utilities are expected to begin using greater quantities of coal now that few major hydroelectric sites remain undeveloped. If the utilities used the maximum potential amount of available biomass fuel, the use of coal could be significantly impacted. An estimated 77.6 TBtu of energy is annually available for electric power generation (24 TBtu of refuse-derived fuel from municipal waste, or one half of available municipal waste, 11.5 TBtu of remaining mill residue and 42 TBtu of logging residue remaining after the residential sector collects $75 \%$ of the ir fuel requirements). The impact of this fuel switching would not result, as seen in Table 16, in any increase in the amount of particulate emissions per TBtu end-use energy for coal to wood conversions because of emission controls and similar operations characteristics. But, the burning of refuse-derived fuel instead of coal would increase particulate emissions by 191 tons/TBtu of end-use energy.

\section{Food and Kindred Products Sector Fuel}

Agricultural waste would be expected to be utilized primarily by the food and kindred products sector. If agricultural waste were burned as a fuel source to the maximum extent possible, the present annual oil and gas requirements of this sector could be reduced by about $80 \% .(45,46)$ The food products industry assumed growth rate of about $2 \%$ per year through the year 2000 parallels that of the agricultural sector in general. As a result, the ratio of agricultural waste to the $0 i 1$ and gas requirements in the year 2000 remains the same as in the late seventies. Agricultural waste is assumed to increase from 19.4 TBtu to $27.1 \mathrm{TBtu}$ while oil and gas demand increases from 24.2 TBtu to 34 TBtu. In Washington and Idaho, the use of agricultural waste could reduce oil and gas requirements by $71 \%$ and $76 \%$, respectively. Agricultural waste in Oregon could replace all oil and gas use. The air-quality implications of this displacement can be noted in Table 14. There is an increase of 349 tons of 
particulate emissions per TBtu of end-use energy from the direct controlled burning of agricultural waste in place of natural gas (93\% of the industry's fuel use is natural gas).

\section{General Industrial Sectors}

Municipal waste could provide up to 48 TBtu of energy in the year 2000. Based on several current projects and reports, it appears feasible that some portion of the waste would be used for electric power production while another portion would provide heat from industrial processes. Of the 48 TBtu available, it was assumed that one half might go to electric power utilities as refuse-derived fuel, consequently reducing their coal requirements. The remaining 24 TBtu of municipal waste would be incinerated by the general industrial sector to displace their oil and gas use.

To assess the air-quality impacts from the use of biomass fuels in place of conventional fuels, the end-use energy from the various fuel-combustion processes had to be calculated. The results of this exercise are presented in Table 15. A regional total of 118.1 TBtu of end-use energy is produced from 290 TBtu of biomass material or 246.1 TBtu of conventional fuels. The need for 54 TBtu more biomass energy is a result of the conversion efficiencies of the combustion systems in which the biomass material is used (see Table 14). The particulate emissions for each combustion process were estimated based on the end-use energy information listed in Table 15 and the particulate emission factors presented in Table 14. Table 16 presents the air emission estimates for each fuel-combustion process.

\subsubsection{Air Emissions Conclusions}

The full utilization of biomass fuels to replace conventional fuels use in the Pacific Northwest region in the year 2000 would increase the amount of particulate emissions by over 99,000 tons per year. Table 16 shows the impact of each method of biomass burning on the region's total biomass-related particulate emission levels of almost 102,000 tons per year. The conventional fuels displaced, oil, gas and coal, by biomass fuels would discharge only 2,400 tons per year while providing the same quantity of end-use energy. Nearly 90,000 tons per year of the biomass related increase would be due to residential wood 
TABLE 15. Biomass End-Use Energy and Conventional Energy Displaced by Biomass - Yr 2000 (1012 Btu/yr)

\begin{tabular}{|c|c|c|c|c|c|c|c|c|c|c|c|c|c|c|}
\hline & \multicolumn{8}{|c|}{ BIOMASS } & \multicolumn{6}{|c|}{ CONVENTIONAL } \\
\hline & 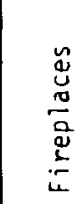 & 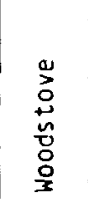 & 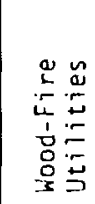 & 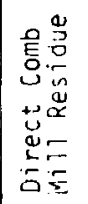 & 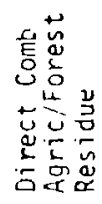 & 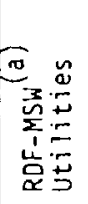 & 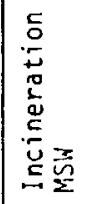 & 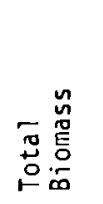 & 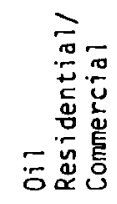 & : & 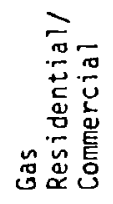 & 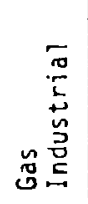 & 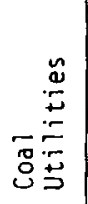 & 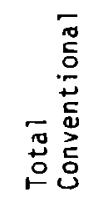 \\
\hline rashington & 3.0 & 21.8 & 6.4 & 5.1 & 7.2 & 4.6 & 8.4 & 56.5 & 8.3 & 3.7 & 8.3 & 17.0 & 19.2 & 56.5 \\
\hline Oregon & 2.0 & 14.5 & 6.8 & 5.6 & 3.4 & 2.9 & 5.3 & 40.5 & 5.5 & 3.1 & 5.5 & 11.2 & 15.2 & 40.5 \\
\hline I daho & 0.8 & 5.7 & 5.0 & 1.6 & 6.1 & 0.7 & 1.2 & 21.1 & 2.2 & 0.6 & 2.2 & 8.3 & 7.8 & 21.1 \\
\hline $\begin{array}{l}\text {.orthwest } \\
\text { Region }\end{array}$ & 5.8 & 42.0 & 18.2 & 12.3 & 16.7 & 8.2 & 14.9 & 118.1 & 16.0 & 7.4 & 16.0 & 36.5 & 42.2 & 118.1 \\
\hline
\end{tabular}

(a) Refuse Derived Fuel - Municipal Solid Waste 
TABLE 16. Biomass Particulate Emissions and Conventional Fuel Emissions Displaced by Biomass Yr 2000 (103 tons/yr)

\begin{tabular}{|c|c|c|c|c|c|c|c|c|c|c|c|c|c|c|c|}
\hline & \multicolumn{8}{|c|}{ BI UMASS } & \multicolumn{7}{|c|}{ CONVENTIONAL } \\
\hline & 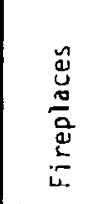 & 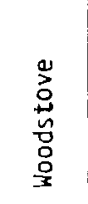 & 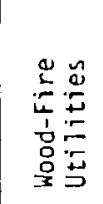 & 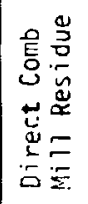 & 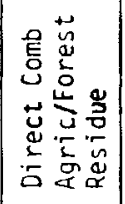 & 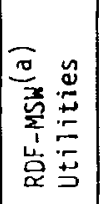 & 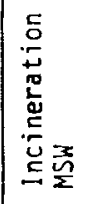 & 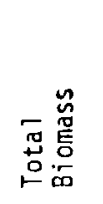 & 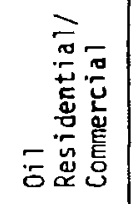 & 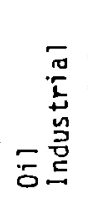 & 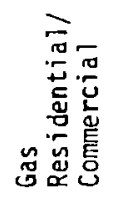 & 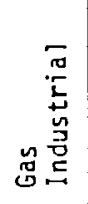 & 竞 & 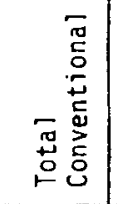 & 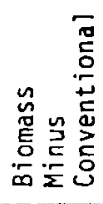 \\
\hline Nashington & 18.2 & 24.5 & 0.2 & 0.8 & 2.6 & 1.0 & 1.0 & 52.1 & 0.4 & 0.2 & 0.04 & 0.08 & 0.4 & 1.2 & 50.9 \\
\hline Oregon & 12.1 & 18.9 & 0.2 & 0.8 & 1.2 & 0.6 & 0.6 & 34.5 & 0.2 & 0.2 & 0.03 & 0.05 & 0.4 & 0.9 & 33.64 \\
\hline Idano & 4.9 & 7.5 & 0.1 & 0.2 & 2.2 & 0.2 & 0.1 & 15.1 & 0.1 & 0.04 & 0.01 & 0.04 & 0.2 & 0.4 & 14.7 \\
\hline $\begin{array}{l}\text { :urthivest } \\
\text { Region }\end{array}$ & 35.2 & 54.9 & 0.5 & 1.8 & 5.9 & 1.8 & 1.7 & 101.7 & 0.7 & 0.5 & 0.08 & 0.17 & 1.0 & 2.4 & 99.3 \\
\hline
\end{tabular}

(a) Refuse Derived Fuel - Municipal Solid Waste 
burning. Although only providing $40 \%$ of the end-use energy from biomass, woodstoves and fireplaces would create $89 \%$ of the biomass-related particulate pollution.

Residential wood burning in the Northwest will not likely ever reach the assessed levels, even if the material were all economically available, without some types of emission controls being imposed on new wood burning appliances. Unfortunately, the effectiveness of such controls on the degradation of the region's air quality from residential wood use may be somewhat questionable. In 1980, already one half of the quantity of wood projected to be consumed in the year 2000 was burned by the residential sector. This use of 3 million cords of wood is estimated to produce approximately 45,000 tons of particulates a year--all of it uncontrolled. Several communities in the Northwest (e.g., Medford and Eugene, Oregon) are having problems meeting the particulate National Ambient Air Quality Standards (NAAQS) due to these woodstove/fireplace emissions. The particulates released from residential wood burning are known to be mostly fine particulates ( $\leq 2.5$ micrograms), which are efficient light scatterers and can penetrate deep into the respiratory system. Also identified in woodstove/fireplace emissions is Polycyclic Organic Matter (POM), which is known animal carcinogens. As a consequence, whatever controls that could be imposed would most likely not be able to reduce the particulate emissions from the 1.4 million woodstoves and fireplaces presently in use in $1980 .(42)$

Burning of logging residues (slash burning) is common practice in the Pacific Northwest. It can be argued that the wood waste is being burned anyway (thus emitting particulates), so why not make use of this available energy in residences. Assuming $70 \%$ of logging wastes in the region are burned with a particulate emission rate of 17 pounds/ton of wood, this translates to nearly 91 thousand tons of particulate per year emitted into the air. This is just slightly more than the estimated 90,000 tons per year from residential woodburning operations. Although quantitatively similar, the impacts from the two methods of uncontrolled residue burning are decidedly different for the following reasons:

1) The majority of the woodstove emissions occur in the winter time when pollutant dispersion conditions are usually poor, whereas slash burning is permitted only during favorable dispersion conditions. 
2) Higher levels of exposure are experienced by the population due to the movement of the source of pollution from the forest closer to the population centers.

Therefore, although the use of biomass as a fuel source may result in 8,300 tons/year increase in the region's air quality $(102,000$ tons/year from biomass fue 1 use versus 93,400 tons/year from conventional fuel use and slash burning), the potential degradation of the air quality within the population centers would be much greater than the regional numerical difference would indicate. To minimize this air quality degradation, there is a need for more detailed examination of the available material, yearly consumption and performance parameters associated with residential wood burning in the populated areas of the Northwest. 



\subsection{CONCLUSIONS}

This brief survey of biomass utilization in the Northwest indicates that the potential energy resource is vast. Estimates of the total potential energy available from biomass are equivalent to one-quarter to one-third of the total energy consumption in the Northwest. A variety of issues will probably constrain actual biomass energy to an amount significantly less than this. However, biomass already contributes $5 \%$ of the energy in the Northwest and this amount will almost certainly increase as a result of the present political interest in biomass energy. Therefore, a careful analys is of the issues related to biomass utilization in the Northwest is important if maximum energy potential is to be achieved with a minimum of social and economic disruption.

Because of the importance of wood products to the Northwest and the recent interest in wood energy, this study has looked at the issues associated with using forest residues as fuel. The Appendix presents a list of the wideranging issues and impacts related to forest residue energy. Section 3 of this paper summarizes a preliminary analysis of the issues of competing end uses for wood residues, forest management policies, injuries and deaths from forest residue collection, and wood use in residential woodstoves. These issues have been identified by many people to be of major importance in the wood energy picture. However, because of the large number of issues associated with using forest residues as energy, it is important to be systematic in evaluating the relevance of further research into a given issue in order not to overlook an issue of major importance. Therefore, in this study, three criterion for judging the importance of further study on an issue were identified:

1. The issue presents a major constraint to the development of wood residues as an energy source.

2. The issue presents a potentially important public policy problem.

3. There are insufficient data presently available with which to gauge the impact of the issue.

In terms of these criterion, the issue of competing end uses for wood residues stands out as a major constraint to the amount of wood residues that will ultimately be available for use as energy. The issue of forest management 
policies may affect the amount of wood residues available but is more important as a public policy problem of trying to mediate among the competing uses for public forestlands. The issue of injuries and deaths in the collection of forest residues is important as a public policy problem and also has had very little data developed in connection with it. The issue of wood use in residential woodstoves is important in several public policy areas including fire safety, poaching of wood on National Forests, and local air quality.

This three-criterion test was used to review the range of issues identified in conjunction with the use of wood residues as an energy source. The following research areas were judged as requiring additional study.

1. A more complete characterization of the wood products and energy markets for wood residues is necessary to project the degree to which wood products uses for wood residues will most likely limit the amount of residues available for energy.

2. Refinement of the analysis of the expected injuries and deaths from collection of forest residues is needed. Verification of the amount of time required to collect slash in relation to merchantable logs using different collection techniques is necessary. Also, a study of the degree to which slash is already being collected for fire prevention or other purposes is needed because it would certainly be considerably safer to remove residues that have already been brought to the roadside than residues still in the forest.

3. The issues surrounding residential woodstove use require further study. In particular, a quantitative study of the local air-quality impacts of woodstove use and more definitive data on the current and projected problems of wood poaching and residential fires caused by woodstoves.

4. Estimation of the effects of the transition from virgin timber to second growth of the Northwest forests on the availability of wood residues is necessary. Also, a projection of the increasing efficiency of utilization of the trees by the wood products industry and the impact on residue availability is needed. 
5. Additional environmental study efforts on the impacts of forest residue removal are needed to determine the impact on soil nutrient levels, soil erosion, and wildlife.

6. To realistically assess the potential of biomass in the Northwest, a study of the synergistic impacts of the above impacts should be performed. This study should consider the needs and institutional difficulties facing the various involved parties with regard to biomass energy. A set of integrated policies with which to encourage use of biomass for energy and mitigate negative impacts should be proposed and examined for indirect effects on the region.

To date, most of the studies of biomass energy potential in the Northwest have concentrated on physically inventorying the available resource and assessing the technological problems and economics of converting biomass to energy. Relatively little work has been done concerning the public policy problems and socioeconomic impacts associated with biomass energy. The preliminary overview in this study indicates that these issues may be very significant determinants of the overall biomass energy picture. Additional research in this area is therefore warranted. 



\subsection{REFERENCES AND NOTES}

1. Outlook for Timber in the U.S., U.S.D.A. Forest Service, 1973, p. 229.

2. An Evaluation of the Use of Agricultural Residues as an Energy Feedstock, Stanford Research Institute, SRI Project 3520. Menlo Park, CA, Juty 1976.

3. Northwest Energy Policy Project: Energy Supply and Environmental Impacts, NEPP Grant No. 6, 1977.

4. Tom Miles, "Biomass in the Northwest--Available Inventory, "Solar 79 Northwest Conference, August 10-12, 1979.

5. John A. Bergva11, Darryl C. Bullington, Loren Gee, William Koss, Wood Waste For Energy Study, Department of Natural Resources, Olympia, Washington, January 1, 1979.

6. It is assumed that all residues listed as "wasted" or "returned" by SRI are available for use as fuel.

7. Conversion made assuming a heat content of $7500 \mathrm{Btu} / \mathrm{lb}$.

8. Conversion made assuming a heat content of $8500 \mathrm{Btu} / \mathrm{lb}$.

9. Conversion made assuming a heat content if $8000 \mathrm{Btu} / \mathrm{lb}$.

10. State portions of the NEPP regional total were estimated from an illustration and therefore represent only approximate resource estimates.

11. "Available" is defined here as that portion of mill wastes which are listed by SRI as currently wasted. This does not include wastes already used as fuel. For a comparison of the respective fractions of mill wastes which are wasted and used as fuel, see discussion in text.

12. Hall, E.H., et al., Comparison of Fossil and Wood Fuels, Battelle-Columbus Lab, Ohio, March 1976. EPA/600/2-76/056.

13. 1976 and 1978 Washington Mill Survey, Washington Mill Survey Series, Reports Nos. 5 and 6 , State of Washington, Department of Natural Resources, Olympia, WA 98504.

14. Grantham, J.B., Energy Potential of Forest Residue, PNW Forest and Range Exper iment Station, U.S.F.S., Seattle, washington, 1979.

15. Biomass Task Force Final Report to the Oregon Alternative Energy Deve1opment Commission, Oregon Department of Energy, Salem, Oregon, 1980.

16. Ross, W., Van Gorkom, J., Scott, B.D., Residue Roundwood and the Washington Pulp Industry, DNR Report No. 35, Washington State Department of Natural Resources, 0lympia, Washington, 1977. 
17. Grantham, J., et a1. Energy and Raw Material Potentials of Wood Residue in the Pacific Coast States - A Summary of a Preliminary Feasibility Investigation, U.S.D.A. Forest Service General Technical Report PNW-18, PNW Forest and Range Experiment Station, U.S.F.S., Portland, Oregon, 1974.

18. Cruickshank, E.D., In-Woods Chipping in Western Oregon, Oregon State Department of Forestry, Salem, Oregon, 1979.

19. The 1980 Report to Congress on the Nation's Renewable Resources, USDA Forest Service, FS-347.

20. Haynes, Richard W., Adams, Darius M., "Impacts of RARE II Withdrawals on Softwood Prices, Consumption, and Production", Journal of Forestry Volume 78, No. 4, Apri1 1979, pp. 230-233.

21. Northcross, Steve, "Initial RARE II Proposals Set All Sides at Odds; Lock Some in Controversy", Timber Harvesting, February 1979, pp. 21-24.

22. Johnson, Huey D., "The Flaws of RARE II", Sierra, May/June 1979, pp. 810 .

23. McComb, John, Scott, Douglas, "RARE II: The Sierra Club's View", Sierra, November/December, 1977, pp. 321-32.

24. Personal correspondence with Steve Levette, Management Information Section, Industrial Safety and Health, Department of Labor and Industries, State of Washington, 01ympia, WA 98504.

25. Goldberg, M.N., Worker Safety in logging Practices, U.S. Dept. of Health, Dept. of Health, Education, and Welfare, April 1974.

26. Hall, E.H., et. al., Environmental and Technological Analys is of the Use of Surplus Wood as an Industrial Fuel. Battelle-Columbus Laboratories, August 1979.

27. Sagan, L.A., "Health Costs Associated With the Mining, Transport and Combustion of Coal in the Steam-Electric Industry," Nature Vol. 250, July 1974, pp. 107-111.

28. Bioenergy Bulletin-Biomass, Vol. 1, No. 6, Pacific Northwest Bioenergy Task Force, U.S. Dept. of Energy, Region X, Seattle Washington, September, 1980.

29. Biomass Task Force Final Report to the Oregon Alternative Energy Development Commission, Oregon Dept. of Energy, Salem, Oregon, June 1980.

30. Energy From Biological Processes, Office of Technology Assessment, Washington, D.C., 1980. 
31. Bergva 11, John, Gee, Loren, Minneman, Kimberly, 1978 Washington Mil1 Survey, Wood Consumption and Mill Characteristics. Washington Mill Survey Series No. 6, Washington State Department of Natural Resources, Olympia, Washington, 1979.

32. Howard, James A., Hiserote, Bruce A. Oregon's Forest Products Industry 1976, USDA Forest Service Resource Bullet in PNW-79, Pacific Northwest Forest and Range Experiment Station, U.S. Department of Agriculture, Forest Service, Portland, Oregon, 1978.

33. Johnson, Leonard R. Quantities and Costs of Wood Biomass in Idaho. Bullet in Number 30, College of Forestry, Wildlife and Range Sciences, University of Idaho, Moscow, Idaho. 1979.

34. Heating With Wood, DOE/CS-0158, U.S. Department of Energy, Washington, D.C., 1980 .

35. Esvelt, Terence G., Roberts, Mark L. "The Use of Wood for Residential Space Heating in the Pacific Northwest." Paper Presented at Solwest ' 80 Joint Solar Conference, August 7, 1980, Vancouver, B.C.

36. Beuter, John H., Johnson, Norman K., Scheurman, Lynn Y. Timber for Oregon's Tomorrow - An Analys is of Reasonably Possible 0ccurances, Research BuTletin 19, Forest Research Laboratory, School of Forestry, Oregon State University, Corvallis, Oregon, 1976.

37. Porterfield, Richard L., Crist, John B, eds., 1978. "Impacts of Changing Quality of Timber Resources," Proceedings of a Joint Meeting of the Economics and Financial Management and Timber Production Technical Committees of the Forest Products Research Society at the 1978 Annual Meeting, June 28, 1978, Atlanta, Georgia.

38. Crop Production 1980 Annual Summary - Acreage Yield Production. U.S. Department of Agriculture Crop Reporting Board, Economics and Statistical Service, Washington, D.C. 1981.

39. Population, Employment and Households - Projections to 2000 for Oregon. U.S. Department of Energy, Bonneville Power Administration, Branch of Power Resources, Portland, Oregon. September 1979.

40. Population, Employment and Households - Projections to 2000 for Idaho. U.S. Department of Energy, Bonneville Power Administration, Branch of Power Resources, Portland, Oregon. February 1980.

41. Population, Employment and Households - Projections to 2000 for Washington. U.S. Department of Energy, Bonneville Power Administration,

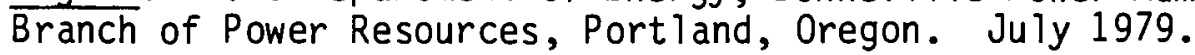

42. Petty, P., Hopp, W., Chockie, A. Biomass Energy Utilization in the Pacific Northwest: Impacts Associated with Residential Use of Solid Fuels. PNL-SA-9618. Pacific Northwest Laboratory, Richland, Washington. 1981. 
43. Wilfert, Pete, McCartney, Heather, Frantzis, Lisa. Regional Energy Environment Data Book: Northwest Region - Volume 1: Energy Draft. PNLRAP-28. Pac ific Northwest Laboratory, Richland, Washington. 1978.

44. Energy Futures Northwest, Northwest Energy Policy Project. Executive Summary of the Final Report. Pacific Northwest Regional Commission, Vancouver, washington. 1978.

45. 1977 Census of Manufacturers, Fuels and Electric Energy Consumed, Part 2. States by Industry Group. MC77-SR-4 (Part 2). U.S. Department of Commerce, Bureau of the Census, Washington, D.C. 1980 .

46. Future Gas Consumption of the United States. Volume 7. Gas Requirements Agency, University of Denver Research Institute. Denver, Colorado. 1977. 
APPENDIX

ENERGY FROM WOOD RESIDUE IN THE PACIFIC NORTHWEST--ISSUES AFFECTING AVAILAB ILITY AND USE 


\section{APPENDIX \\ ENERGY FROM WOOD RESIDUE IN THE PACIFIC NORTHWEST--ISSUES \\ AFFECTING AVAILABILITY AND USE}

I. Physical Quantities of Wood Residue in Northwest

A. Definition and Basic Sources of Wood Residue

B. Amount and Location of Forest Lands--Commercial and Non-commercial

C. Amount of Wood Residue Per Area Per Species

II. Practical Quantities Available

A. Issues Affecting Amount of Available Forested Lands

1. RARE II--Wilderness

2. Recreational, Watershed, Game Preserve Restrictions

3. USFS Land Use Policies--Current and Projected

4. State Land Use Policies--Current and Projected.

5. Bureau of Land Management Land Use Policies--Current and Projected

6. Private Land Owner's Use Policies--Current and Projected

B. Issues Influencing Biomass Availability

1. Crop and Age--Virgin vs. Second Growth Timber

2. Slope Issues $<30^{\circ}$ Oniy

3. Nutrient Requirements of Soil--USFS, State, BLM, Private Policies

4. Slash Removal for Fire Control

5. Slash Removal for Insect Control

6. Sldsh Removal for Aesthetic Reasons

7. Fire Potential from Increased Slash Operations

8. Accidents and Injuries from Increased Slash Collection

9. Erosion Problems from Slash Removal

10. Road Requirements--Building New, Maintaining Old

11. Impacts on Wildlife and Fish

12. Seasonality of Collection Impacts

III. Economics of Collection

A. Volume/Acre and Scattered State of Logging Residue

B. Transportation Issues

1. <40 Miles to a Market

2. Current and Projected State of Chip Hauling Equipment

C. Relative High Risk

1. Insurance Issues

2. Projected Cost of Injuries

A. 1 
D. Difficulty in Determining Actual Logging Costs for Residue and of Relating Estimated Costs to Specific Operating Situation

E. Payments to Operator Crew on Basis of Net, Rather Than Gross Scale

F. Competitive Pressure on Logging Firms to Keep Net Volume Produced at High-Level--Maximize Use of Crew and Equipment Resources

G. Contract Constraints

1. Contract Provisions for Residue Disposal/Utilization
a. USFS
b. State
c. BLM
d. Private Owners

2. Risk That Some Pieces Would be Scaled and Graded as Merchantable Logs

H. Residue for Products

1. Difficulty in Setting Specifications for Acceptable Material

2. Piece-By-Piece Inspection to Weed Out Cull

3. Lack of Sorting Facilities at Mills or Landings

4. Lack of Chipping Facilities at Mills

I. Current State of Chipping Operations

IV. Competing End Uses

A. Industry Use of Wood Residue--Amounts Past and Future

1. Pulpwood

2. Residue Lumber (Particle Board) and Veneer

3. Export of Chips, or Residue

B. Effects of Economic Conditions at Any Given Point in Time of Profitability of Residue for Products

C. Wood Resource Contract Constraints

1. Logging or Mill Companies' Contracts Internal to Industry

2. Logging or Mill Companies' Contracts to Other Users

3. Logging or Mill Companies' Contracts to Utilities

D. Ability of Mills to Absorb More Residue for Product Production

E. Forest Industry Energy Requirements and Current/Future Energy Sources (Based on Industry Perspective) 
F. Problems of Using Wood for Energy By Forest Industry

1. Storage Requirements

2. Handling Costs

3. Air Quality Issues

G. Composition and Size of Forest Industry in Northwest

1. Location With Respect to Slash Areas

2. Location With Respect to Problem Air Quality Areas

V. Non-Forest Industry Energy From Wood Issues

A. Residential Wood Stoves

1. Safety Hazards from Stoves
a. Fires
b. Wood Handling Accidents

2. Wood Quantity Needed to Fuel Stoves--Inefficient and Efficient Models
a. Sources of Wood
b. Transportation/0il. Use Impacts from Collection

3. Collection Accidents--Lost Days and Hospital Costs

4. Economics of Residential Collection and Use

5. Improper and Unauthorized Cutting

B. Electric Utilities Use of Wood

1. Supply Requirements
a. Supply Contracts--Length of Contract Issues
b. Quantities Required
c. Source of Wood--Logging Industry or Others

2. Air Quality and Residual Disposal Issues
a. Control Technology Issues
b. Siting With Respect to Air Quality Regions--Transportation Concerns
c. Construction and Licensing Requirements

3. Economics of Utilities' Wood Use

C. Commercial and Industrial Use of Wood for Energy

1. Potential Amounts of:
a. Cogeneration
b. Electrical Generation
c. Heat Only Generation 
2. Siting and Size of Users

3. Wood Supply Issues
a. Contract Issues
b. Quantities Required
c. Handling and Storage Issues

4. Air Quality and Residual Disposal Issues

a. Siting with Respect to Air Quality Regions

b. Efficiencies of Generation Facilities

VI. Conclusions and Recommendations
A. How Much Will Actually be Available for Energy Use?
B. Who Will Collect the Wood for Energy?
C. Who Will Use the Wood?
D. What Will be the Impacts--Environmentally, Socially, Institutionally, Economically?
E. Potential Methods to Maximize Use and Reduce Adverse Impacts.
F. Potential Range of Future Consumption Levels by Sector. 
PNL -3933

UC-61

\section{DISTRIBUTION}

No. of

Copies

OFFS ITE

A. A. Churm

DOE Patent Division

9800 S. Cass Avenue

Argonne, IL 60439

25 Gregory J. D'Alessio

Environmenta 1 Technology Division

U.S. Department of Energy

EP-23 Germantown

MS $E-277$

Washington, D.C. 20545

27 DOE Technical Information Center

Dr. John Bergvall

Washington State Department of Natural Resources

Olympia, WA 98504

Richard E. Schaefer

Bonneville Power Administration

P.0. Box 3621

Portland, OR 97208
No. of

Copies

ONS ITE

DOE Richland Operations Office

H. E. Ransom

55 Pac if ic Northwest Laboratory

K. J. Allwine

W. J. Bair

D. L. Brenchley

A. D. Chockie (35)

W. J. Hopp (5)

Technical Information (5)

Publishing Coordination KE(2)

Economics Library (5) 
